Review

\title{
A Series of Data-Driven Hypotheses for Inferring Biogeochemical Conditions in Alkaline Lakes and Their Deposits Based on the Behavior of $\mathrm{Mg}$ and $\mathrm{SiO}_{2}$
}

\author{
Jasmine E. Chase (D), Maria L. Arizaleta and Benjamin M. Tutolo *(D) \\ Department of Geoscience, University of Calgary, Calgary, AB T2N 1N4, Canada; \\ jasmine.chase@ucalgary.ca (J.E.C.); arizalet@ualberta.ca (M.L.A.) \\ * Correspondence: benjamin.tutolo@ucalgary.ca
}

Citation: Chase, J.E.; Arizaleta, M.L.; Tutolo, B.M. A Series of Data-Driven Hypotheses for Inferring Biogeochemical Conditions in Alkaline Lakes and Their Deposits Based on the Behavior of $\mathrm{Mg}$ and $\mathrm{SiO}_{2}$. Minerals 2021, 11, 106. https:// doi.org/10.3390/min11020106

Academic Editor: Anna H. Kaksonen Received: 23 December 2020

Accepted: 18 January 2021

Published: 22 January 2021

Publisher's Note: MDPI stays neutral with regard to jurisdictional claims in published maps and institutional affiliations.

Copyright: (c) 2021 by the authors. Licensee MDPI, Basel, Switzerland. This article is an open access article distributed under the terms and conditions of the Creative Commons Attribution (CC BY) license (https:// creativecommons.org/licenses/by/ $4.0 /)$.
Abstract: Alkaline ( $\mathrm{pH}>8.5)$ lakes have been common features of Earth's surface environments throughout its history and are currently among the most biologically productive environments on the planet. The chemistry of alkaline lakes favors the deposition of aluminum-poor magnesian clays (e.g., sepiolite, stevensite, and kerolite) whose chemistry and mineralogy may provide a useful record of the biogeochemistry of the lake waters from which they were precipitated. In this forward-looking review, we present six data-driven, testable hypotheses devoted to furthering our understanding of the biogeochemical conditions in paleolake waters based on the geochemical behavior of $\mathrm{Mg}$ and $\mathrm{SiO}_{2}$. In the development of these hypotheses, we bring together a compilation of modern lake water chemistry, recently published and new experimental data, and empirical, thermodynamic, and kinetic relationships developed from these data. We subdivide the hypotheses and supporting evidence into three categories: (1) interpreting paleolake chemistry from mineralogy; (2) interpreting the impact of diatoms on alkaline lake sedimentation; and (3) interpreting depositional mineralogy based on water chemistry. We demonstrate the need for further investigation by discussing evidence both for and against each hypothesis, which, in turn, highlights the gaps in our knowledge and the importance of furthering our understanding of the relevant geological and biological systems. The focused testing of these hypotheses against modern occurrences and the geologic record of alkaline lakes can have profound implications for the interpretation of the paleo-biogeochemistry and paleohabitability of these systems on Earth and beyond.

Keywords: alkaline lake; soda lake; Mg-silicates; diatoms; biogeochemistry; clay minerals; diagenesis

\section{Introduction}

\subsection{Motivation and Direction of the Review}

Alkaline lakes and their mineral deposits are present through much of Earth's geological record [1-3] and may have also occurred in the sedimentary record of other terrestrial planets [4-6]. They are among the most biologically productive environments on the planet [7-9] and have likely contributed to carbon cycling on a planetary scale over Earth's history [10-12]. Geochemical modeling even suggests that carbonate-rich lakes formed early in Earth's history could have given rise to its first organisms [6]. Recent work has also implied that synthetic versions of these lakes can help combat global climate change by assisting in the production of algal biofuels [13]. Meanwhile, the discovery of vast hydrocarbon reservoirs in ancient alkaline lake deposits on the south Atlantic coastal margins has prompted renewed interest in these systems from energy producers [14-22]. Altogether, the diversity of researchers studying alkaline lakes and their deposits demonstrates that these systems are dynamic, biogeochemical hotspots worthy of continued study.

The mineral assemblages produced by alkaline lake systems often feature some combination of silicate clays, carbonates, and various evaporite minerals [1,23]. Over 40 years ago, Eugster and colleagues [1,24,25] established a flow diagram, based on the concept of 
chemical divides, to map the evolution of lacustrine brine geochemistry as source waters are evaporatively concentrated. Divides occur when specific chemical constituents (e.g., $\mathrm{Ca}$ and /or $\mathrm{Mg}$ ) are diminished by mineral precipitation as waters evaporate, such that further evaporation will lead to a different mineral assemblage than if that constituent were not diminished. Using the chemical divides concept $[1,24,25]$ the presence of these mineral groups can provide important insight into the biogeochemistry of the lake that deposited them. For example, the presence or absence of gypsum $\left(\mathrm{CaSO}_{4} \cdot 2 \mathrm{H}_{2} \mathrm{O}\right)$ can provide insight into the lacustrine sulfur cycle [1]. Moreover, diagnostic morphologies of carbonate minerals precipitated from alkaline lake waters can yield useful inferences about lacustrine $\mathrm{pH}$ and $\mathrm{SiO}_{2}$ (aq) concentrations [26]. In turn, these observations can be complemented with studies of clay mineral geochemistry to yield more specific insight into the lake water chemistry [23].

As pointed out by Eugster and Hardie [24], Mg-silicate clay precipitation is possible for most paths through the chemical divide flow diagram. In this forward-looking review, we present a series of testable hypotheses for using the mineralogy of alkaline lake deposits, particularly the presence of various Al-poor Mg-silicate minerals, to make more granular inferences about the paleochemistry of the water from which they were deposited than would be permitted by the chemical divides concept alone. Although some hypotheses are more controversial than others, we make every attempt to collect and present supporting and opposing evidence for each hypothesis. In turn, we hope that these hypotheses will help to direct the future of research into magnesian clays and alkaline lake deposits, and their potential for interpreting the biogeochemical evolution of our planet and other bodies in our solar system.

\subsection{Geochemistry of Alkaline Lakes}

Alkaline lakes are defined here as lacustrine systems with a $\mathrm{pH}$ of 8.5 or greater. These environments develop through evaporative concentration of underfilled lakes with source waters containing ratios of the concentration of $\mathrm{Ca}^{2+}$ to alkalinity under $2 \mathrm{~mol} / \mathrm{mol}$, which yields elevated $\mathrm{pH}$ following the nearly quantitative removal of $\mathrm{Ca}^{2+}$ as solid $\mathrm{CaCO}_{3}$ during the early stages of evaporation [27]. This evaporation process yields elevated concentrations of conservative tracers such as $\mathrm{Cl}^{-}$and $\mathrm{Na}^{+}$commensurate with the degree of evaporation [24]. Concentrations of $\mathrm{Mg}^{2+}$, on the other hand, typically only yield similar increases until the solubility of a Mg-bearing phase (e.g., Mg-bearing clays or carbonates) is exceeded [28-30]. $\mathrm{SiO}_{2}$ (aq) concentrations, in turn, often follow the trends exhibited by $\mathrm{Mg}^{2+}$ concentrations, but can also be controlled by other biogeochemical processes (Figure 1). $\mathrm{Al}^{3+}$ concentrations in lake waters typically decrease as a result of increasing evaporative concentration $\left(\mathrm{Al}^{3+}\right.$ solubility is sensitive to elevated fluid $\mathrm{pH}$ and typically conserved in a solid phase) [24]. In the advanced stages of evaporation, alkaline lake chemistry is dominated by varying proportions of $\mathrm{SiO}_{2}(\mathrm{aq}), \mathrm{Ca}^{2+}, \mathrm{Mg}^{2+}$, $\mathrm{Na}^{+}, \mathrm{K}^{+}, \mathrm{Cl}^{-}, \mathrm{HCO}_{3}{ }^{-}, \mathrm{CO}_{3}{ }^{2-}$ and $\mathrm{SO}_{4}{ }^{2-}$, which can be predicted and evaluated using the "chemical divides" flow diagram of brine evolution [1,24,25]. Importantly, one of the uniting characteristics of alkaline lakes is that they contain significantly more inorganic carbon than natural waters with circumneutral $\mathrm{pH}$ (e.g., seawater [31]), which gives rise to these uniquely productive, apparently non-carbon limited ecosystems [7-9].

Clay minerals deposited in lacustrine sediments can be dominantly aluminous (e.g., kaolinite), magnesian (e.g., talc), or both (e.g., saponite) [23]. In keeping with the goals of the present study, we focus our introduction on $\mathrm{Al}$-poor Mg-silicates, because aluminous clays are unlikely to provide a directly interpretable record of the chemical conditions of lake waters, given the minimal aqueous $\mathrm{Al}$ concentrations in alkaline lakes, which limits their precipitation. Rather, aluminous clays in alkaline lake deposits likely reflect the process of detrital clay input (i.e., freshening events [32]) and diagenetic transformations [33]. Since the properties and origin of Al-poor Mg-silicate minerals have been thoroughly and extensively reviewed elsewhere [21,22], we only provide a brief summary here. 


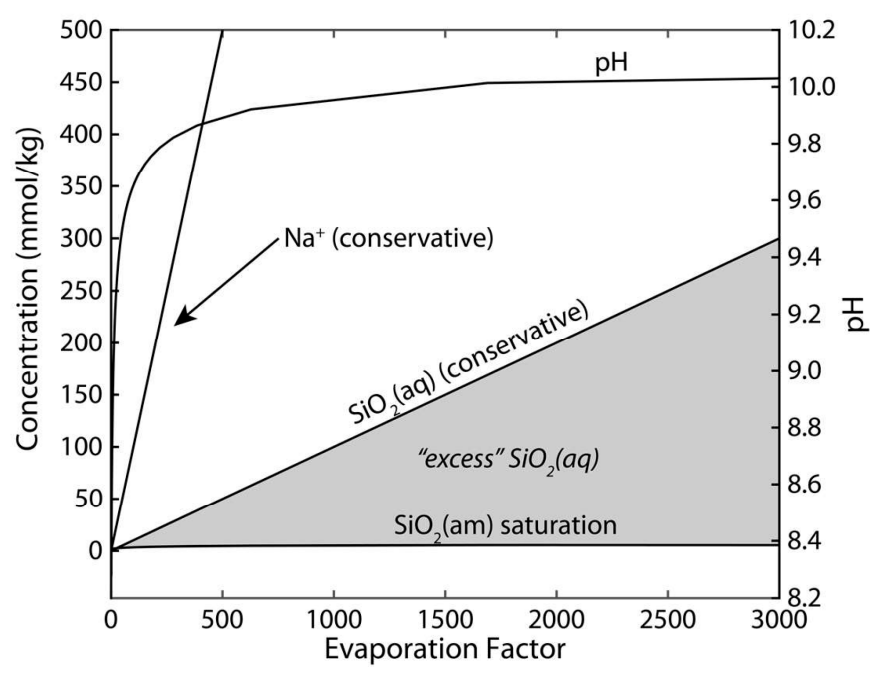

Figure 1. Evolution of $\mathrm{pH}$ and $\mathrm{Na}$ and $\mathrm{SiO}_{2}(\mathrm{aq})$ concentrations during evaporation of a water initially containing $0.2 \mathrm{mmol} / \mathrm{L} \mathrm{Ca}, 1 \mathrm{mmol} / \mathrm{L} \mathrm{Na}, 1 \mathrm{mmol} / \mathrm{L} \mathrm{HCO}_{3}{ }^{-}$. Partial pressure of $\mathrm{CO}_{2}(\mathrm{~g})$ is fixed at $10-3.5$ bars. Two values for the concentration of $\mathrm{SiO}_{2}(\mathrm{aq})$ are plotted: (1) the concentration of $\mathrm{SiO}_{2}$ (aq) behaved conservatively during evaporation; (2) the concentration of $\mathrm{SiO}_{2}$ (aq) limited by the solubility of amorphous silica $\left(\mathrm{SiO}_{2}(\mathrm{am})\right)$. Geochemical modeling methods are described in Appendix A.

Talc $\left(\mathrm{Mg}_{3} \mathrm{Si}_{4} \mathrm{O}_{10}(\mathrm{OH})_{2}\right)$ and /or its hydrated equivalent, kerolite $\left(\mathrm{Mg}_{3} \mathrm{Si}_{4} \mathrm{O}_{10}(\mathrm{OH})_{2} \cdot \mathrm{H}_{2} \mathrm{O}\right)$, sepiolite $\left(\mathrm{Mg}_{2} \mathrm{Si}_{3} \mathrm{O}_{7.5}(\mathrm{OH}) \cdot 6 \mathrm{H}_{2} \mathrm{O}\right)$, and stevensite (a poorly defined trioctahedral smectite with the idealized formula $\left(\mathrm{M}^{+}{ }_{2 \mathrm{y}} \cdot n \mathrm{H}_{2} \mathrm{O}\right)\left(\mathrm{Mg}_{3-\mathrm{y}} \square_{\mathrm{y}}\right) \mathrm{Si}_{4} \mathrm{O}_{10}(\mathrm{OH})_{2}$, where $\mathrm{M}^{+}$is an exchangeable interlayer cation (monovalent in this case), $\square$ represents $y$ vacancies and $n$ is variable) are common in alkaline lake deposits [21,23]. The structural distinctions between these $\mathrm{Mg}$ silicate minerals yield variable ratios of $\mathrm{Mg}$ to $\mathrm{Si}$. Each mineral has an ideal stoichiometric $\mathrm{Mg} / \mathrm{Si}$ ratio: 0.75 for talc/kerolite, 0.67 for sepiolite, and $\sim 0.67-0.75$ for stevensite [34], although it has become clear that even apparently mineralogically pure phases can have chemistry that deviates from this ideal ratio [22,35,36], and lake deposits often contain mixtures or interlayers of multiple separate minerals [34,37-39]. Importantly, stevensite, as a trioctahedral smectite, has a positive charge deficit and thus often contains additional cations such as $\mathrm{Na}^{+}$. Moreover, loughlinite $\left(\mathrm{Na}_{2} \mathrm{Mg}_{3} \mathrm{Si}_{6} \mathrm{O}_{16} \cdot 8\left(\mathrm{H}_{2} \mathrm{O}\right)\right)$, the sodium analog of sepiolite, has been observed in some locales [40].

While it has long been established that there is a relationship between Mg-rich silicate clays and fluid $\mathrm{pH}[28,41-43]$, experimental studies of the past decade have begun to uncover a correlation between other aspects of fluid chemistry (e.g., the $\mathrm{Mg} / \mathrm{Si}$ ratio) and the Mg-silicate mineral chemistry [35,44,45].

\section{Data-Driven Hypotheses for Interpreting Paleolake Chemistry}

In this section, we begin with a set of hypotheses specifically discussing the potential for using Mg-silicate minerals in alkaline lake deposits to constrain chemical conditions of the ancient lake systems that deposited them.

\subsection{Hypothesis 1}

Mg-silicates authigenically precipitated from alkaline lakes are thought to pass through an initial, amorphous or gel-like stage before ultimately maturing to their crystalline counterparts $[14,15,23,30,42-47]$. The rate of this conversion depends on the temperature and chemical conditions accompanying the reaction [35,43,48], but often appears to go to completion, since the presence of amorphous components has not been demonstrated in mineralogical analyses of ancient lacustrine sediments [21,22,32]. That observation notwithstanding, it is interesting to note that environmental conditions on Mars have conspired to preserve amorphous materials over billions of years [49,50]. Together, these observations 
suggest that there is a role for the gel precursor in the potential pathways to $\mathrm{Mg}$-silicate crystallization. Yet, the most important question to answer for our current effort is: Do the chemistry and mineralogy of the geologically preserved $\mathrm{Mg}$-silicate phase(s) reflect the chemistry of the lake from which the gel precipitated?

Due to the high reactivity of $\mathrm{Mg}$-silicates in pore waters [35], it seems likely that the gel-to-crystalline transformation often occurs during the earliest stages of diagenesis, i.e., during shallow sediment burial. Indeed, experiments mimicking this process in low water-to-rock ratio environments (i.e., pore waters occluded from overlying lake waters) demonstrate significant progress toward the conversion of an almost completely x-ray amorphous gel to a moderately crystallized phase after heating at $60{ }^{\circ} \mathrm{C}$ for just 356 days (Figure 2). Importantly, in these experiments, which are described in Appendix B, the crystallographic reflections characteristic of talc/kerolite, which are weakly visible or absent in the initial analysis, dramatically increase in strength after heating. Similarly, Tosca et al. [43] heated an amorphous gel with chemical and spectroscopic properties representative of kerolite for 4 weeks at $180{ }^{\circ} \mathrm{C}$ and 4 days at $400{ }^{\circ} \mathrm{C}$. In both cases, the resultant mineral showed clear increases in crystallinity, with the sample heated to higher temperature demonstrating more significant increases in crystallinity compared with the one heated to lower temperature. The observation that the peaks do not shift (e.g., to indicate crystallization of sepiolite from the initial kerolite-like gel) gives evidence in support of Hypothesis 1. Additional experimental examples of this transformation from amorphous to crystalline clay minerals abound in the literature [21,39,51-56], although the context of each individual study and its applicability to testing Hypothesis 1 vary. One salient feature gleaned from many of these is the utility of vibrational spectroscopy (most typically Fourier-transform infrared spectroscopy, FTIR) for characterizing the chemical bonding environments of the initial, amorphous phases [42-45].

a

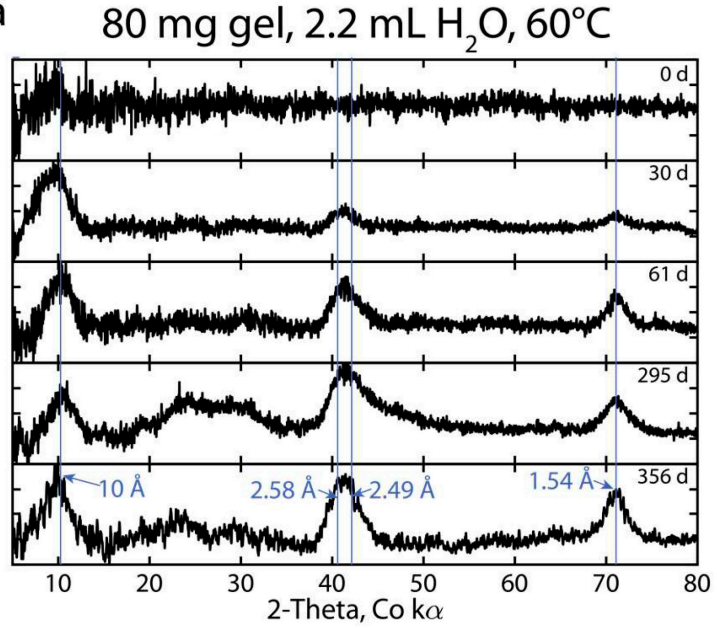

b

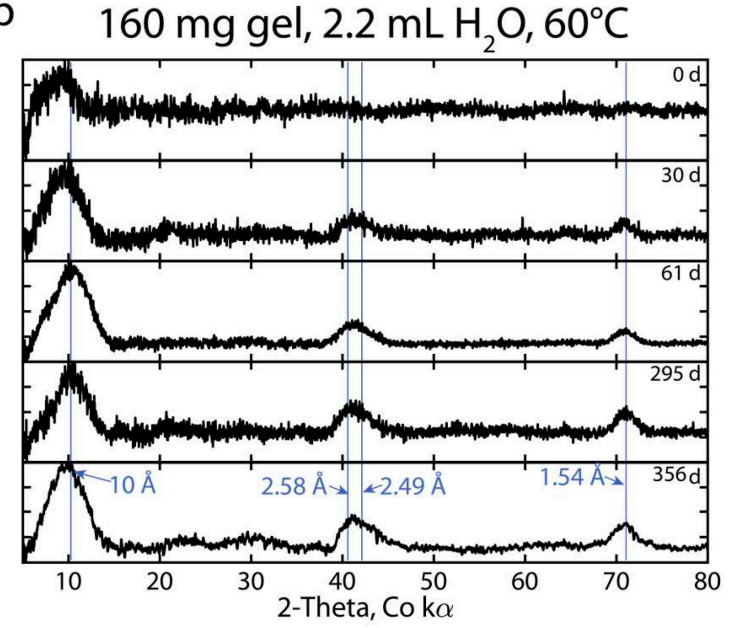

Figure 2. X-ray diffraction analyses of Mg-silicate gel after heating at $60{ }^{\circ} \mathrm{C}$ for durations up to 356 days (see Appendix B for experimental details). Values of d-spacing relevant to crystalline talc are indicated. (a) Heated material containing $80 \mathrm{mg}$ Mg-silicate gel per $2.2 \mathrm{~mL} \mathrm{H}_{2} \mathrm{O}$, (b) Heated material containing $160 \mathrm{mg}$ Mg-silicate gel per $2.2 \mathrm{~mL} \mathrm{H}_{2} \mathrm{O}$.

Hypothesis 1. Mineralogy and Chemistry of Al-Poor Mg-Silicate Clays in the Sedimentary Record of Alkaline Lakes Directly Reflect the Mineralogy and Chemistry of the Initially Precipitated Material, Even If That Material Was Amorphous at the Time of Deposition.

Evidence in opposition to this hypothesis stems from the sheer complexity of factors contributing to potential mineral transformations during diagenesis [57]. Natural diagenetic processes can be difficult to constrain and predict, and alkaline lake systems, which are commonly located in tectonically active rift environments [58], can demonstrate an uncommonly complex array of diagenetic reactions $[15,17,59,60]$. A particularly 
poignant example comes from the observation of loughlinite in the Green River Formation of Wyoming. Fahey et al. [40] described this mineral as replacing the initial mineralogy of the shale in which it is found, and also showed that it rapidly and completely transforms to sepiolite when soaked in a Mg-rich solution. A second example is the apparently complete, stoichiometric removal of Mg-silicate matrix material from shrub facies in the Barra Velha Formation, which has been taken as evidence to suggest significant changes in fluid chemistry (e.g., $\mathrm{pH}$ decreases) during diagenesis $[15,16,60]$. These observations demonstrate quite clearly that silicate-bearing sediments can, given the right conditions (e.g., dramatic contrasts between depositional and diagenetic fluids), transform dramatically or even disappear during diagenesis. In these cases, the observed phase or mineral assemblage may be chemically distinct from that which was initially deposited and thus have very little relation to the chemical composition of the paleolake waters. At the same time, these examples demonstrate that proper petrographic screening (e.g., the identification of overprinting features in hand samples or thin sections) can allow for these issues to be identified and avoided. Nevertheless, it is likely the textural complexity of multi-mineralic rocks derived from alkaline lakes would tend to compound the difficulty in interpretation.

Based on the body of literature reviewed in this section, it seems that Hypothesis 1 is potentially correct in some environments and incorrect in others. Regardless, these collected results would caution against using "big data" evaluations of stratigraphic records (e.g., obtained through drilling or systematic sampling of outcrops) without the establishment of strict petrographic screening criteria that would eliminate or at least minimize the chances of significant diagenetic overprinting.

\subsection{Hypothesis 2}

Pozo and Galán [21] recently evaluated the role of $\mathrm{pH}$ (and partial pressure of $\mathrm{CO}_{2}$, $\left.P_{\mathrm{CO} 2}\right) ; \mathrm{Mg}$, Si and $\mathrm{Al}$ concentrations; and salinity on $\mathrm{Mg}$-silicate formation. We briefly summarize their results here, with supplements based on works published in the intervening time. Firstly, the $\mathrm{pH}$ of waters must rise above a certain $\mathrm{pH}(\sim 8.3$ [42] or $~ 8.6$ [43]) to homogeneously nucleate $\mathrm{Mg}$-silicate gel. Tosca et al. [43] identified that even elevated $\mathrm{Mg}$ and $\mathrm{Si}$ concentrations in solution at $\mathrm{pH}$ less than the threshold are insufficient to cause Mg-silicate precipitation, as $\mathrm{pH}$ above $\sim 8.5$ causes the dissociation of silicic acid, leading to increased concentrations of a dissolved $\mathrm{Mg}-\mathrm{SiO}_{2}$ complex $\left(\mathrm{MgH}_{3} \mathrm{SiO}_{4}{ }^{+}\right)$, which could precede the gel precipitate. Because lake water $\mathrm{pH}$ is linked to $p_{\mathrm{CO} 2}$, increases and decreases in $p_{\mathrm{CO} 2}$ can yield decreases and increases, respectively, in $\mathrm{pH}[61,62]$, even potentially leading to Mg-silicate dissolution if $\mathrm{pH}$ drops low enough [15]. Secondly, the relative concentrations of $\mathrm{Mg}, \mathrm{Si}$, and $\mathrm{Al}$ have been shown to exert a control on the chemistry of the precipitated phase $[35,41,44,45,63,64]$. As the $\mathrm{Mg} / \mathrm{Si}$ ratio of the fluid increases from low $(<1)$ to high $(>1)$ values, the stoichiometry of the precipitated phase increases accordingly, such that kerolite-like and stevensite-like precipitates are increasingly favored over sepiolite-like precipitates. Across this range, $\mathrm{Na}^{+}$concentrations can also play a role, since the size of $\mathrm{Na}^{+}$ions is apparently compatible in the $\mathrm{Mg}^{2+}$ site in $\mathrm{Mg}$-clays, unlike other common monovalent cations (e.g., $\mathrm{K}^{+}$), leading to the precipitation of loughlinite, or loughlinite-sepiolite solid-solution [40,45]. Finally, studies of natural deposits supplemented by stable isotope stratigraphy [65,66], modern lake systems [28,67], high-salinity experiments [44,45], and thermodynamic calculations [41] all suggest that elevated salinity should favor precipitation of stevensite, rather than sepiolite or kerolite.

Considering these various controls on the potential mineralogy of alkaline lake deposits in the context of the present review leads to the question: What useful information about the paleochemistry of an alkaline lake can be gleaned from the mineralogy observed in an alkaline lake deposit? The experimental and field studies discussed in this section permit the assertion that the presence of authigenic $\mathrm{Mg}$-silicate clays in lacustrine deposits implies precipitation from alkaline, potentially saline, lake waters. Given the preponderance of recent experimental studies examining the role of dissolved $\mathrm{Mg}$ and $\mathrm{Si}$ in the character of Mg-silicate precipitates, it may be possible to build this qualitative framework into a 
more quantitative, predictive model. To this end, we collected relevant experimental data (described in Appendix C) to attempt to discern the relationship between $\mathrm{Mg} / \mathrm{Si}$ of experimental fluids and $\mathrm{Mg} / \mathrm{Si}$ of experimentally precipitated solids at ambient temperatures (Figure 3). Fitting the collected data to an equation of the form:

$$
\eta_{s}=\frac{a}{\left(\eta_{f}\right)^{b}}+c
$$

where $\eta_{s}$ is the $\mathrm{Mg} / \mathrm{Si}$ molar ratio in the precipitated solid, $\eta_{f}$ is the $\mathrm{Mg} / \mathrm{Si}$ molar ratio in the fluid from which it was precipitated, and $a, b$, and $c$ are fitting parameters, permits incorporation of the knowledge that crystallographic constraints suggest the $\eta_{s}$ should approach some finite maximum value with increasing $\eta_{f}$ (i.e., $\eta_{s}$ should not exponentially or even linearly increase above some value of $\eta_{f}$ ). Unweighted fitting of Equation (1) to the collected data yields:

$$
\eta_{s}=\frac{-0.16}{\left(\eta_{f}\right)^{0.49}}+0.90
$$

with $r^{2}=0.75$ (when considering uncertainties on individual values of $\eta_{f}$ ). This line asymptotically approaches $\eta_{s} \approx 0.8$ as $\eta_{f}$ approaches and exceeds 5 , which is consistent with talc $\left(\eta_{s}=0.75\right)$ precipitation from ancient seawater with elevated $\mathrm{Mg} / \mathrm{Si}$ [43].

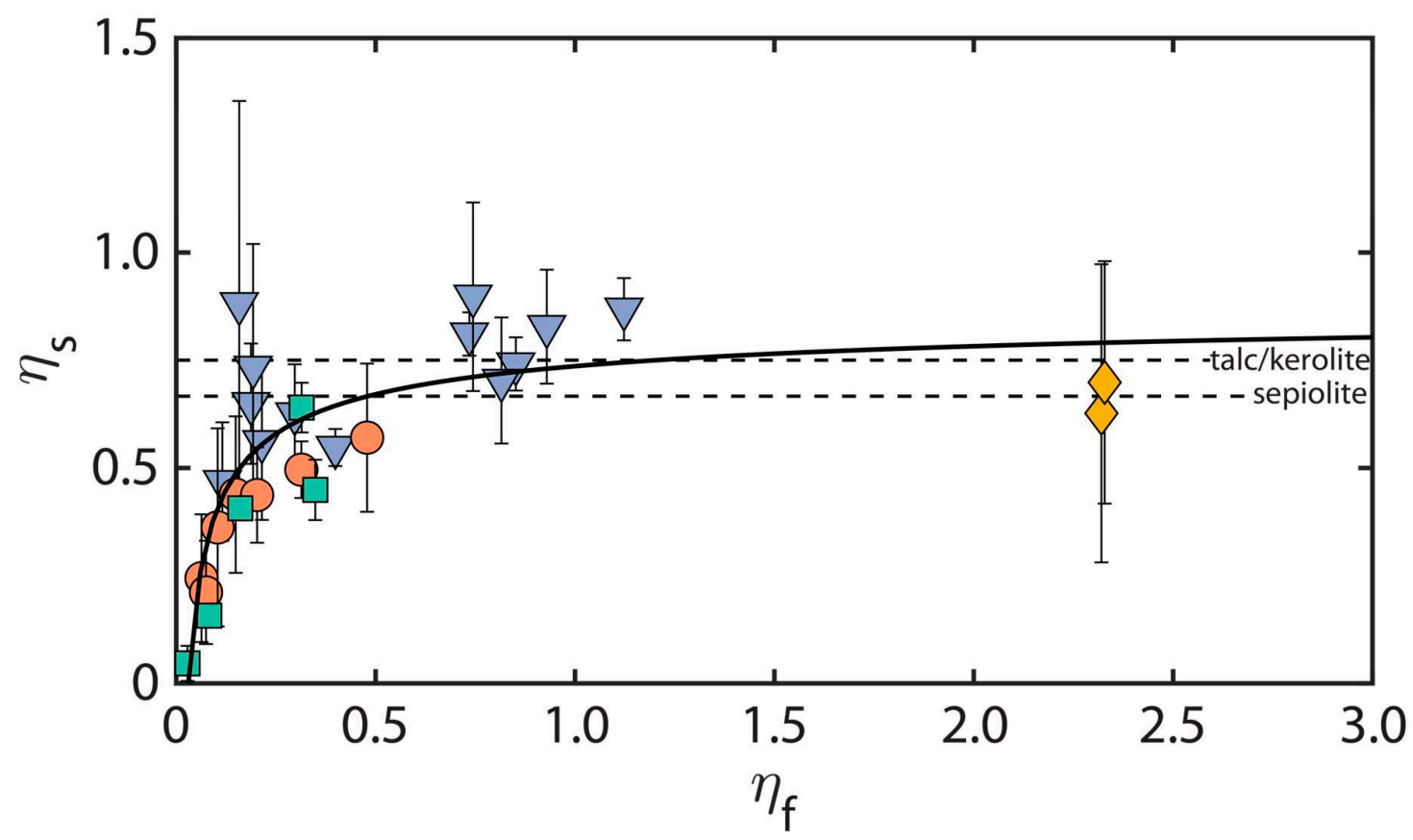

Figure 3. Values of the $\mathrm{Mg} / \mathrm{Si}$ ratio of experimentally grown solids $\left(\eta_{s}\right)$ plotted as a function of the $\mathrm{Mg} / \mathrm{Si}$ ratio of the fluid from which they were precipitated $\left(\eta_{s}\right)$. A line fitted to the data Equation (2) is plotted, and ideal values of $\eta_{s}$ for sepiolite and talc/kerolite are plotted for reference. Experimental precipitation was conducted in the pH range 9.2-10.2, as detailed in Appendix C, well above the $\mathrm{pH}$ threshold for $\mathrm{Mg}$-silicate precipitation [42,43].

As discussed by references [35] and [45], the precipitates represented by non-stoichiometric values of $\eta_{s}$ are likely either non-ideal or mixtures of mineral-like (e.g., loughlinite, kerolite, stevensite, and sepiolite) precipitates. In this context, it is important to consider the nature of salinity and $\mathrm{Na}^{+}$concentrations in alkaline lakes. Because the primary mechanism by which these lakes become alkaline is through evaporative concentration, even in lakes with minimal initial $\mathrm{Na}^{+}$concentrations in their source waters, $\mathrm{Na}^{+}$will drastically increase with increasing $\mathrm{pH}$, such that any alkaline lake with a $\mathrm{pH}>9$ is likely to have significant 
total dissolved solids (Figure 1). Thus, although salinity in alkaline lakes can be relatively high or low (e.g., Lake Yoa has relatively high salinity with total dissolved solids (TDS) at $12,900 \mathrm{~g} / \mathrm{L}$ compared to lakes of the Pastos Grandes with TDS 13-27 g/L [28,68]), even a low salinity alkaline lake will contain significant salinity compared to other, fresher natural waters. Accordingly, although elevated $\eta_{f}$ can yield solids with $\eta_{s}$ representative of kerolite or stevensite, the threshold for favoring one or the other cannot be directly discerned from the experimental studies we collected. Likewise, the potential for precipitating solids with $\eta_{s}$ representative of loughlinite-sepiolite mixtures at low values of $\eta_{f}$ also suggests a role for $\mathrm{Na}^{+}$and salinity, which would challenge the oft-cited assertion that stevensite represents high salinity deposits.

Much of the literature reviewed in this section provides either qualitative or quantitative support of Hypothesis 2, which is based on Figure 3 and the predictive capacity of Equation (2). Nevertheless, the subset of these sources that provide quantitative support for this hypothesis were used in the creation of Figure 3, and the argument in support of Hypothesis 2 is thus somewhat circular. For this reason, it will be important to produce quantitative observations of modern lake systems and/or renewed efforts into the types of diagenetic experiments described in Section 2.2 to allow for a more rigorous test of this hypothesis.

Hypothesis 2. Ratios of the Concentrations of $\mathrm{Mg}$ and Si in Paleolake Waters Can Be Estimated from Observed $\mathrm{Mg}$-Silicate Clay Mineralogy and Chemistry.

\section{Data-Driven Hypotheses for Interpreting the Impact of Diatoms on Alkaline Lake Sedimentation}

In this section, we build upon the preceding chemical discussion to generate a set of hypotheses specifically discussing the impact of diatoms on the mineralogical record of alkaline lake deposits.

\subsection{Hypothesis 3}

Silica-secreting diatoms play a governing role in setting the concentrations of $\mathrm{SiO}_{2}(\mathrm{aq})$ in Earth's oceans [69-73] and many of its lakes [24,74,75]. The distribution of diatom species in lake sediments is frequently used as a tool to place constraints on salinity of ancient lake waters [76], and there is some evidence that the presence, absence, and/or diversity of diatom species can be indicative of variations in $\mathrm{pH}[77,78]$. Nevertheless, much of the evidence correlating lake $\mathrm{pH}$ with diatom assemblages focuses on circumneutral and acidic $\mathrm{pH}$ environments, and there are far fewer studies of diatoms inhabiting alkaline lakes. Importantly, as the $\mathrm{pH}$ of alkaline lakes increases toward and above the dissociation $\mathrm{pH}$ for silicic acid ( $\mathrm{pH} \approx 9.9$ [79]), silica solubility increases exponentially, thus presenting specific challenges for the livelihood of silica-secreting diatoms.

Common marine phytoplankton species demonstrate highest growth rates at $\mathrm{pH} 7.5-8.0$, with growth either drastically slowing (by up to $90 \%$ ) or terminating completely between pH 8.8 and 9.6 [80-83]. While samples of alkaline lakes have demonstrated diatom existence in lakes with $\mathrm{pH}$ as high as $10.5[68,74,84]$, it is not clear how productive the organisms are at the highest $\mathrm{pH}$. In general, it seems that the upper $\mathrm{pH}$ limit of diatom growth is 9.5 or 10 [82]. Breakdown of the microbial and algal communities in Canadian alkaline lakes indicates the presence of diatoms, but only as a minor proportion of the community [8]. Competition for vital resources rather than physiological factors may ultimately be limiting for these organisms. Notably, the dissociation $\mathrm{pH}$ for ammonia is 9.2 , and $\mathrm{pH}>9.2$ promotes ammonia volatility and nitrogen limitation [5], which would tend to compound the struggles for diatoms in their competition with other alkaline lake-dwelling organisms such as cyanobacteria.

Based on these combined observations, it seems likely that, as the $\mathrm{pH}$ of alkaline lake waters approaches and exceeds $~ 9.5$, diatoms are increasingly unlikely to be dominant primary producers or dominant sinks for silica in alkaline lake systems. This conclusion would tend to support Hypothesis 3. However, there are few published studies that allow 
this hypothesis to be tested in an unambiguous manner, and it may very well be that the existing studies are limited in their applicability to high-pH alkaline lake systems. In any case, the effective testing of this hypothesis in the context of the fluid $\mathrm{Mg} / \mathrm{Si}$ ratio $\left(\eta_{f}\right)$ control on Mg-silicate mineralogy (Hypothesis 2) could facilitate inferences of alkaline lake paleohabitability based on the mineralogy of the associated deposits.

Hypothesis 3. At $p H \gtrsim 9.5$, Diatoms Are Rarely the Dominant Primary Producer in Alkaline Lakes, and Are Consequently Not Responsible for Significant Undersaturation with Respect to Amorphous Silica.

\subsection{Hypothesis 4}

The utility of uniformitarianism as a guide for interpreting Earth's history is often disrupted by biogeochemical innovations that suddenly and drastically change the processes contributing to the construction of the rock record. In the case of alkaline lakes, a sudden and extreme shift in the silica cycle may have dramatically changed the mineralogical record of these environments. Although diatoms are common in many modern lacustrine systems, they are fairly recent evolutionary additions. Geologic and molecular lines of evidence suggest that lacustrine diatoms emerged in the early Miocene [85], 23 Ma or more recently, descended from marine species that radiated throughout the marine environments earlier in the Cenozoic $[72,86]$.

Although land plants have been biomineralizing silica throughout Phanerozoic time [87], it is unlikely that these organisms ever appreciably affected the silica concentrations of alkaline lakes, which are often hostile to their growth (as evidenced by the lack of vegetation near the shores of many alkaline lakes). As these organisms are not present in alkaline lakes, $\mathrm{Mg}$-silicates and amorphous silica precipitation remain as the probable silica sinks prior to the Miocene. With limited silica removal from evaporative lakes, $\mathrm{SiO}_{2}$ concentrations would rise (Figure 1), and the resulting lower $\mathrm{Mg} / \mathrm{Si}$ ratios $\left(\eta_{f}\right)$ should have favored the precipitation of sepiolite over kerolite and stevensite (Figure 3). Available mineral evolution data aligns with this hypothesis - the mineral evolution database [88] suggests lacustrine sepiolite appeared earlier in the geologic record (in a deposit as old as $105 \mathrm{Ma}$ [89]) than stevensite (in deposits with a maximum age of $56 \mathrm{Ma}[90,91]$ ). The mineral evolution database could easily be missing earlier occurrences of both, and follow-up work can help to clarify the history of occurrence of these minerals in alkaline lake deposits. Importantly, the circa 2.7 Ga Rietgat Formation (South Africa), hypothesized to have been deposited from an alkaline lake, contains bedded chert, which would be consistent with deposition as amorphous silica during evaporative concentration of the ancient lake waters (Figure 1). Nevertheless, testing Hypothesis 4 in the context of the geologic record of alkaline lake deposits could ultimately assist in interpreting paleohabitability and paleochemistry of alkaline lakes on Earth before silica-secreting diatoms began to inhabit alkaline lake systems, as well as other planets where such complex organisms are unlikely to have evolved.

Hypothesis 4. Prior to the Expansion of Diatoms into Continental Settings, $\mathrm{SiO}_{2}$ Concentrations in Alkaline Lakes Could Only Have Been Limited by Amorphous Silica or Mg-Silicate Precipitation, such that Mg/Si Ratios Were Low, and the Dominant Mg-Silicate Mineralogy Should Have Been Sepiolite.

\section{Data-Driven Hypotheses for Interpreting Depositional Mineralogy Based on Water Chemistry (and Vice Versa)}

Data from natural systems can help to contextualize the largely empirical discussion above with active Earth surface processes. The wealth of alkaline lakes on Earth today has made it possible to create a comprehensive database of lake water chemical analyses. This data set (described in more detail in Appendix D) contains unpublished analyses from Canadian lakes and published analyses from various authors over the past 100 years $[8,28,29,62,67,68,75,76,92-101]$ detailing locations including Last Chance and Goodenough Lakes (Canada), Lake Yoa waters and brines (Chad), Bolivian Salars (Bolivia), 
Lake Eyasi Basin (Tanzania), Lerai (Tanzania), Pastos Grandes (Bolivia), Lake Van (Turkey), and Lake Neusiedl (Austria). Collected fluid samples include not only lake waters but also fluid chemistry data for associated springs, groundwaters, porewaters, and inflowing rivers and streams (which presumably represent source fluids). Samples were screened to remove those with charge balance errors $> \pm 10 \%$. Where multiple samples exist from a single location, all values were included, since the nature of alkaline lakes can yield chemical and mineralogical variation over modest spatial and temporal scales (e.g., [28]).

The compiled data set permits calculation of the activities of $\mathrm{Mg}^{2+}$ and $\mathrm{SiO}_{2}(\mathrm{aq})$ and saturation indices of relevant phases for all compiled samples except those missing a vital analysis (e.g., $\mathrm{pH}, \mathrm{Mg}$, or $\mathrm{SiO}_{2}$ (aq) concentration). These calculations demonstrate that all but a fraction of the samples are undersaturated or near equilibrium with respect to amorphous silica $\left(\mathrm{SiO}_{2}(\mathrm{am})\right.$ ) (Figure 4a) and fall below the critical supersaturation for $\mathrm{Mg}$-silicate nucleation (Figure $4 \mathrm{~b}$ ). There is no clear trend in the $\mathrm{SiO}_{2}(\mathrm{am})$ saturation state as $\mathrm{pH}$ increases from source $\mathrm{pH}(\approx 7)$ toward alkaline lake $(>8.5) \mathrm{pH}$, but, over this same progression, it approaches the Mg-silicate nucleation threshold ( $y$-axis $=0$ in Figure $4 \mathrm{~b}$ ) and levels off (although it is worth noting the dramatic difference in the $y$-axis scales of Figure $4 a, b)$.
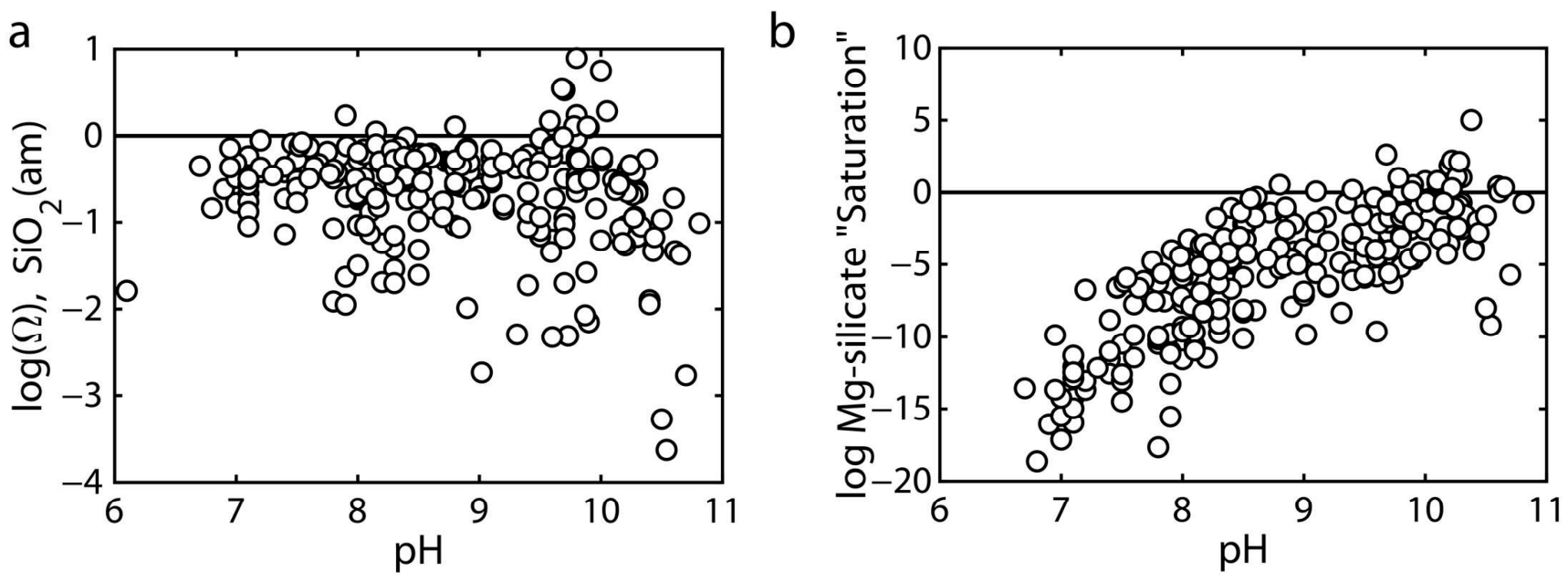

Figure 4. Calculated values of solution saturation state with respect to: (a) Amorphous silica $\left(\mathrm{SiO}_{2}(\mathrm{am})\right)$, and (b) the critical supersaturation for Mg-silicate nucleation for all values in the alkaline lake database, including "source" waters such as groundwaters and springs.

The lack of a correlation between $\mathrm{pH}$ and saturation state with respect to amorphous silica (Figure 4a) suggests that a sink for $\mathrm{SiO}_{2}(\mathrm{aq}$ ) other than amorphous silica leads to significant amorphous silica undersaturation in the compiled samples. This, together with the correlation between $\mathrm{pH}$ and the approach to $\mathrm{Mg}$-silicate nucleation threshold, suggests a role for silica-secreting organisms (i.e., diatoms) and/or $\mathrm{Mg}$-silicate nucleation and growth in controlling alkaline lake water chemistry.

Values of the ratio of the activities of $\mathrm{Mg}^{2+}\left(a_{\mathrm{Mg}^{2+}}\right)$ to $\mathrm{SiO}_{2}(\mathrm{aq})\left(a_{\mathrm{SiO}_{2}(\mathrm{aq})}\right)$ calculated from the collected alkaline $(\mathrm{pH}>8.5)$ lake data generally follow the trend represented by the theoretical ratio corresponding to amorphous silica saturation and the critical supersaturation for Mg-silicate nucleation (Figure 5a). This ratio is roughly consistent with $\eta_{f}$ defined above, and thus could help to guide interpretations of ancient lake water chemistry on the basis of observed mineralogy. However, it differs in one important way: It accounts for variations in fluid chemistry (e.g., ionic strength) from sample to sample through the calculation of speciation and activity coefficients. Notably, at the elevated ionic strengths of some of the collected samples, the activity coefficient of $\mathrm{Mg}^{2+}$ drops far below unity and, thus, plotting activities rather than concentrations permits a more proper comparison. Values of this ratio for the alkaline lake samples plot both 
above and below the theoretical line (Figure 5a), although fewer plot below, and even those are mostly within an order of magnitude of the theoretical line. The vast majority $(149 / 161$, or $93 \%)$ of collected samples are undersaturated with respect to amorphous silica, and quite a significant proportion of these $(132 / 149$, or $82 \%$ of all samples) are both undersaturated with respect to amorphous silica and fall below the critical threshold for $\mathrm{Mg}$-silicate nucleation (Figure $5 \mathrm{~b}$ ). These observations point toward potential mechanisms that are promoting and/or inhibiting the growth of Mg-bearing minerals in modern alkaline lakes, and these may be explored via the following two hypotheses.

a

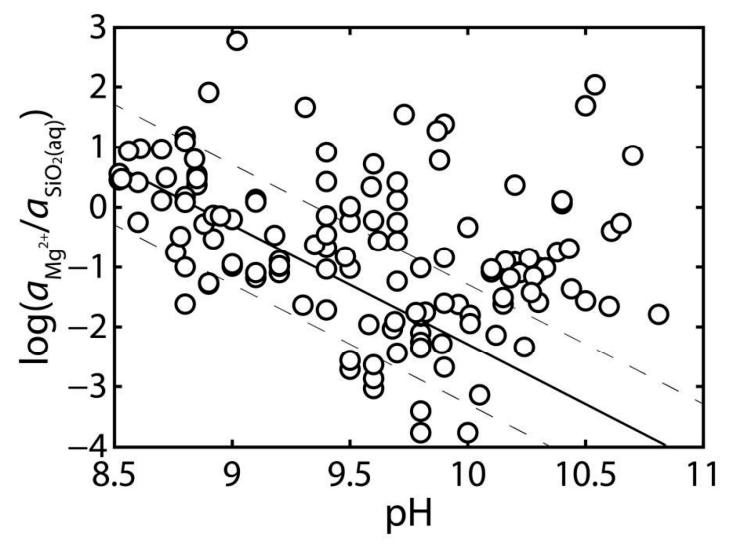

b

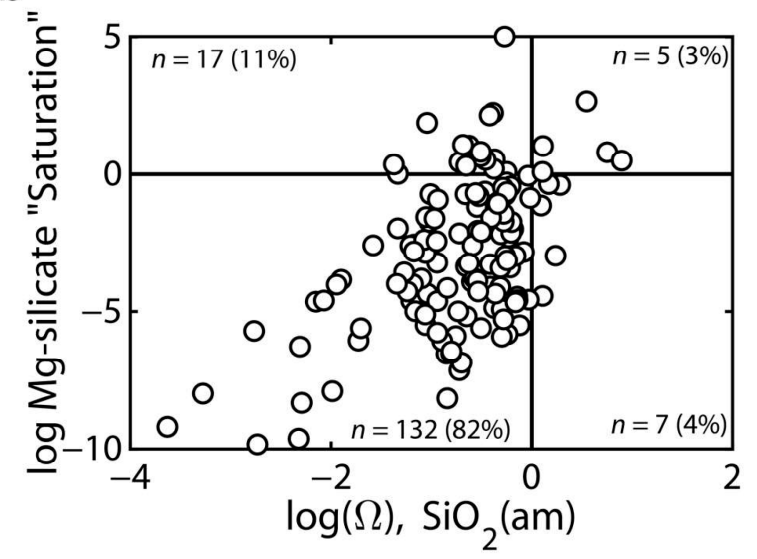

Figure 5. (a) Comparison between calculated values of the ratio of the activities of $\mathrm{Mg}^{2+}\left(a_{\mathrm{Mg}^{2+}}\right)$ to $\mathrm{SiO}_{2}(\mathrm{aq})\left(a_{\mathrm{SiO}_{2}(\mathrm{aq})}\right)$ and the theoretical ratio corresponding to amorphous silica saturation and the critical supersaturation for $\mathrm{Mg}$-silicate nucleation (solid black line), both of which are calculated according to equations and thermodynamic data presented by Refs. [35] and [45]. One order of magnitude variation in the theoretical line is plotted for reference. (b) Cross-plot of saturation state of $\mathrm{SiO}_{2}(\mathrm{am})$ and the critical supersaturation required for $\mathrm{Mg}$-silicate nucleation, denoting the number of samples and percentage of the overall data set falling in each quadrant. All values in $\mathrm{b}$ were calculated for solutions with $\mathrm{pH}>8.5$.

\subsection{Hypothesis 5}

When the collected alkaline lake samples plot above the theoretical baseline defined by amorphous silica saturation and the critical supersaturation for Mg-silicate nucleation, their elevated $\mathrm{Mg} / \mathrm{Si}$ ratio generally corresponds to undersaturation with respect to amorphous silica and a failure to exceed the threshold for $\mathrm{Mg}$-silicate nucleation at that $\mathrm{pH}$ (Figure $5 \mathrm{~b}$ ). As discussed in Section 1.2, even if un-evaporated alkaline lake source waters contain modest concentrations of $\mathrm{SiO}_{2}(\mathrm{aq})$, these concentrations will tend to approach and exceed saturation with respect to amorphous silica after fairly insignificant degrees of evaporation (Figure 1). The observation that many of the samples in Figure 4 are undersaturated with respect to amorphous silica thus suggests that they must have deposited $\mathrm{SiO}_{2}$ in another form (e.g., as diatom frustules or as (Mg-silicate clays). If diatoms are the dominant silica sink, the sedimentary record would also reflect deposition of diatom-rich sediments (i.e., diatomite e.g., [102]). Although diatom consumption of $\mathrm{SiO}_{2}(\mathrm{aq})$ necessarily reduces the thermodynamic drive for precipitation of authigenic Mg-silicate clays, there is evidence that diatom frustules can lower the barrier for nucleation of Mg-silicates [67,103]. By decreasing $\mathrm{SiO}_{2}(\mathrm{aq})$ concentrations in lake waters, diatoms can effectively increase the $\mathrm{Mg} / \mathrm{Si}$ ratio in that water, which would potentially tend to favor talc/kerolite and/or stevensite over sepiolite precipitation from lake water in authigenic minerals (Section 2). In the absence of diatoms, potentially as a result of high $\mathrm{pH}$ (Section 3.1), or prior to the radiation of lacustrine species (Section 3.2), $\mathrm{SiO}_{2}(\mathrm{aq})$ concentrations below amorphous silica saturation would most likely be explainable by the precipitation of (Mg-)silicate clays. In this case, the mineralogy and lake water chemistry could potentially co-vary, depending on the initial $\mathrm{Mg} / \mathrm{Si}$ ratio, the $\mathrm{Mg} / \mathrm{Si}$ ratio of the precipitated phase, and the initial volume of water in the lake, and thereby present variations in mineralogy along an evaporative 
sequence. In the case of either diatoms or Mg-silicate clays limiting the concentrations of silica in alkaline lake waters, the $\mathrm{Mg}$ - and Si-bearing phases in alkaline lake sediments could provide clues as to the $\mathrm{Mg} / \mathrm{Si}$ ratio of the lake waters. Calculations of the type presented in Figure 5 could help to guide these interpretations and the focused testing of Hypothesis 5.

Hypothesis 5. Fluid Mg/Si Ratios Rising above a Theoretical Line Defined by Amorphous Silica Saturation and the Critical Supersaturation for Mg-Silicate Nucleation Are Most Likely Caused by Diatoms, or, in Their Absence, the Precipitation of Silicate Clays.

\subsection{Hypothesis 6}

When the compiled lake samples plot below the theoretical baseline defined by amorphous silica saturation and the critical supersaturation for Mg-silicate nucleation, their $\mathrm{Mg} / \mathrm{Si}$ ratio is potentially lower as a result of $\mathrm{Mg}$ precipitation in Si-free phases (i.e., a (Ca-)Mg-carbonate). Magnesian carbonates have been identified in association with alkaline lake deposits (e.g., [45]), although the presence of magnesite and dolomite (which are not known to precipitate at low temperatures) in ancient systems is most likely due to original deposition of hydromagnesite $\left(\mathrm{Mg}_{5}\left(\mathrm{CO}_{3}\right)_{4}(\mathrm{OH})_{2} \cdot 4 \mathrm{H}_{2} \mathrm{O}\right)$, high-Mg calcite, or other metastable hydrated $\mathrm{Mg}$ carbonate phases (e.g., nesquehonite) that have been found to precipitate in these natural systems and under experimental conditions [24,29,42,75,95,104,105]. Of particular note may be the modern day alkaline and ephemeral lakes associated with the Coorong Lagoon that precipitate $\mathrm{Mg}$ carbonate phases, including dolomite, alongside chert, and where seasonal fluctuations in $\mathrm{pH}$, drying and wetting of shallow lake basins, and biological processes may all play a role in the deposition of these phases [106].

The observation that somewhat fewer (50/137, or $37 \%$ ) of the values of the $\mathrm{Mg} / \mathrm{Si}$ ratios for the lake samples plot below the theoretical line (Figure 4 ), and even those that do are generally within an order of magnitude of the line and tend to follow the line's trend with increasing $\mathrm{pH}$, suggests that this theoretically calculated line, or a modified version thereof, could be an approximate lower threshold for $\eta_{f}$ in alkaline lakes. If this were the case, it would be generally consistent with the scarcity of precipitated clays with exceptionally low $\eta_{s}$ (Figure 3) in the rock record. Nonetheless, should Hypothesis 6 be proven correct by study of lakes where magnesian carbonates are actively precipitating, lacustrine $\mathrm{Mg}$-carbonates in the rock record would indicate removal of $\mathrm{Mg}$ from solution without a corresponding decrease in $\mathrm{Si}$, with direct implications for the biogeochemical processes that occurred in those ancient lake systems.

Hypothesis 6. Fluid Mg/Si Ratios Falling below a Theoretical Baseline Defined by Amorphous Silica Saturation and the Critical Supersaturation for Mg-Silicate Nucleation Are Most Likely Caused by the Precipitation of Mg-Carbonates.

\section{Outlook}

Alkaline lake environments occur at the intersection of biology and geology, requiring an inherently multidisciplinary approach. The experimental, field, and theoretical data and calculations we collected here, along with the six hypotheses we posed, are aimed to inspire discussion and future studies across these disciplines and their relevant sub-disciplines. Through the synthesis and presentation of these hypotheses we highlight the controlled laboratory investigations and extensive field studies into $\mathrm{Mg}$-silicates that are paving the way for application of biogeochemical proxies to the interpretation of ancient alkaline lakes. In each case, we used the collected evidence to generate the relevant hypotheses, and this data may also be useful in testing the accuracy of the individual hypotheses. The ambiguous, conflicting, and/or incomplete nature of the collected references (e.g., there are few studies with extensive reporting of both lake water chemistry and sediment mineralogy) will manifest unique challenges for future researchers and perhaps serve as a guide for designing future studies. There remain many promising avenues for research 
designed to refine our understanding of these complex, dynamic biogeochemical systems, and we hope that this work will help to guide that research.

Supplementary Materials: The following are available online at https:/ / www.mdpi.com/2075-163 X/11/2/106/s1, and all data plotted in Figures 4 and 5. Spreadsheet S1: Alkaline Lake Chemistry Database; Dataset S1: Mg/Si Data plotted in Figure A1.

Author Contributions: Conceptualization, B.M.T.; data curation, J.E.C.; investigation, B.M.T., M.L.A.; writing—original draft preparation, J.E.C.; writing—review and editing, J.E.C., M.L.A. and B.M.T. All authors have read and agreed to the published version of the manuscript.

Funding: We acknowledge support from the Natural Science and Engineering Research Council of Canada under Discovery Grant number RGPIN-2018-03800, the Donors of the American Chemical Society Petroleum Research Fund, and the University of Calgary Program for Undergraduate Research Experience for this work and related research.

Institutional Review Board Statement: Not applicable.

Informed Consent Statement: Not applicable.

Data Availability Statement: All data plotted in all figures are included as Supplemental Material.

Acknowledgments: The authors wish to extend their sincere gratitude to Francis Wu for inviting us to contribute this work to the "10th Anniversary of Minerals: Frontiers of Mineral Science" issue. In addition, we thank Chris Tino (UC Riverside) for a fruitful discussion on the biogeochemical dynamics of alkaline lakes and Alex Paquette (University of Calgary) for his assistance navigating microbiological literature. The authors also thank Shane Bossaer and Zhengqiang Che (both University of Calgary) for sharing data in advance of publication. Finally, Michael Nightingale (University of Calgary) is thanked for his assistance in analyzing experimental samples presented here via ICP-OES. Finally, we thank two anonymous reviewers for reading and commenting on this manuscript.

Conflicts of Interest: The authors declare no conflict of interest.

\section{Appendix A. Geochemical Modeling}

The Geochemist's Workbench, outfitted with the geochemical thermodynamic database presented by Tutolo and Tosca [45], was used in reaction path modeling of the evaporative evolution of the geochemistry of a simplified synthetic lake water. The water initially contained $0.2 \mathrm{mmol} / \mathrm{L} \mathrm{Ca}, 1 \mathrm{mmol} / \mathrm{L} \mathrm{Na}, 0.1 \mathrm{mmol} / \mathrm{kg} \mathrm{SiO}_{2} / \mathrm{kg}$ (in the "conservative" model), $1 \mathrm{mmol} / \mathrm{L} \mathrm{HCO}_{3}{ }^{-}$, and the partial pressure of $\mathrm{CO}_{2}(\mathrm{~g})$ was fixed throughout the simulation at $10^{-3.5}$ bars. The reaction path simulation was run twice: once where the concentration of $\mathrm{SiO}_{2}(\mathrm{aq})$ behaved conservatively during evaporation (i.e., the precipitation of Si-bearing minerals was suppressed), and a second time where the concentration of $\mathrm{SiO}_{2}(\mathrm{aq})$ concentration was limited by the solubility of amorphous silica $\left(\mathrm{SiO}_{2}(\mathrm{am})\right)$. The "theoretical" $\mathrm{Mg} / \mathrm{Si}$ ratio, defined by saturation with respect to $\mathrm{SiO}_{2}(\mathrm{am})$ and the nucleation threshold for Mg-silicate clays was also calculated using this model. Specifically, the critical supersaturation $\left(K_{\text {critical }}\right)$ for $\mathrm{Mg}$-silicate precipitation was calculated according to:

$$
\mathrm{K}_{\text {critical }}=\frac{a_{\mathrm{Mg}^{2+}}^{3} a_{\mathrm{SiO}_{2}(\mathrm{aq})}^{4} a_{\mathrm{H}_{2} \mathrm{O}}^{4}}{a_{\mathrm{H}^{+}}^{6}}=10^{34},
$$

and the solubility of $\mathrm{SiO}_{2}(\mathrm{am})$ according to:

$$
K_{\mathrm{SiO}_{2}(\mathrm{am})}=a_{\mathrm{SiO}_{2}(\mathrm{aq})}=10^{-2.73} .
$$

Assuming $a_{\mathrm{H}_{2} \mathrm{O}} \approx 1$, Equation (A2) can be combined with Equation (A1) to yield an equation relating $a_{\mathrm{Mg}^{2+}}$ to $\mathrm{pH}$, which can then be used to calculate $a_{\mathrm{Mg}^{2+}} / a_{\mathrm{SiO}_{2}(\mathrm{aq})}$ as a function of $\mathrm{pH}$, as plotted in Figure 5. All speciation calculations in this study employed the extended Debye-Hückel "B-dot" equation for calculating activity coefficients of charged aqueous species and assumed a value of unity for the activity coefficients of neutral species. 


\section{Appendix B. Mg-Silicate Gel Crystallization Experiments}

Two sets of Mg-silicate gel crystallization experiments were performed (by B.M.T.) at the University of Oxford. Each experimental series consisted of either 80 or $160 \mathrm{mg}$ of Mg-silicate gel and $2.2 \mathrm{~mL}$ of deionized water in five standard $2 \mathrm{~mL}$ micro-centrifuge tubes. The Mg-silicate gel was prepared in a $\mathrm{pH}=9.8$ (buffered by boric acid [35]) solution with $1.8 \mathrm{mmol} / \mathrm{kg} \mathrm{SiO}_{2}, 50 \mathrm{mmol} / \mathrm{kg} \mathrm{Mg}$, and $50 \mathrm{mmol} / \mathrm{kg} \mathrm{Ca}$, which, according to [43], should yield a solid precipitate with talc or kerolite-like $\mathrm{Mg} / \mathrm{Si}$ ratio. The experiments were initialized by sinking the tightly sealed micro-centrifuge tubes into a water bath held constant at $60{ }^{\circ} \mathrm{C}$ over the duration of the experiments. At fixed times over the course of the experiments (after 0, 30, 61, 104, 295, and 356 days), individual micro-centrifuge tubes were taken from the water bath, their fluid extracted via a needle-tipped syringe, and then dried at $60^{\circ} \mathrm{C}$. After drying, all samples but the 104 day samples (which were inadvertently destroyed prior to analysis) were analyzed via powder X-ray diffraction using a Panalytical Empyrean Pro powder X-ray diffractometer outfitted with a Co X-ray source at the University of Oxford, and the accompanying fluid was filtered through a $0.2 \mu \mathrm{m}$ filter, acidified with nitric acid, and analyzed using a Perkin Elmer Optima 7300 DV Inductively Coupled Plasma-Optical Emission Spectroscopy (ICP-OES) at the Scottish Universities Environmental Research Centre (SUERC) in Glasgow, Scotland, United Kingdom. Background-subtracted XRD analyses are presented in Figure 2 in the main text, and Table A1 contains fluid chemistry for all analyzed samples. Ca and $\mathrm{Si}$ were below the detection limit $(1 \mathrm{mg} / \mathrm{L})$ in all samples, but, notably, the $\mathrm{Mg}$ and $\mathrm{Na}$ concentrations were elevated in the experiments with the lower water-to-mineral ratio (160 mg mineral: $2.2 \mathrm{~mL} \mathrm{H}_{2} \mathrm{O}$ ).

Table A1. Fluid chemistry data from Mg-silicate crystallization experiments.

\begin{tabular}{|c|c|c|c|}
\hline Sample & Elapsed Time (days) & $\mathrm{Mg}(\mathrm{mmol} / \mathrm{L})$ & $\mathrm{Na}(\mathrm{mmol} / \mathrm{L})$ \\
\hline \multicolumn{4}{|c|}{$80 \mathrm{mg}$ gel, $2.2 \mathrm{~mL}$ DI $\mathrm{H}_{2} \mathrm{O}$} \\
\hline 1L-1 & 30 & 13 & 4.9 \\
\hline $1 \mathrm{~L}-2$ & 61 & 13 & 3.9 \\
\hline $1 \mathrm{~L}-3$ & 104 & 14 & 3.8 \\
\hline $1 \mathrm{~L}-4$ & 295 & 18 & 6.1 \\
\hline $1 \mathrm{~L}-5$ & 356 & 19 & 6.4 \\
\hline \multicolumn{4}{|c|}{$160 \mathrm{mg}$ gel, $2.2 \mathrm{~mL}$ DI $\mathrm{H}_{2} \mathrm{O}$} \\
\hline 2L-1 & 30 & 17 & - \\
\hline $2 \mathrm{~L}-2$ & 61 & 21 & 15 \\
\hline $2 \mathrm{~L}-3$ & 104 & 20 & 16 \\
\hline $2 \mathrm{~L}-4$ & 295 & 31 & 23 \\
\hline 2L-5 & 356 & 34 & 24 \\
\hline
\end{tabular}

\section{Appendix C. Precipitation Experiments Methodology}

Data used in the creation of Figure 3 are plotted in Figure A1. Two of these data sets were acquired from previously published studies [35,45], and interested readers are directed to those studies for a description of the experimental methodology. These data were supplemented by an additional series of analyses performed for the present study as well as data from two unpublished experiments performed by Zhengqiang Che (University of Calgary). All data plotted in Figure A1 are provided in a supplemental text file. All new data plotted in Figure A1 were acquired using methods similar to those used by Arizaleta et al. [35]. The experiments plotted in Figure A1c,d utilized a $0.0125 \mathrm{M}$ $\mathrm{NaBO}_{2} \cdot 4 \mathrm{H}_{2} \mathrm{O}$ buffer solution, the $\mathrm{pH}$ of which was adjusted to the desired initial value (10.2) and using $1 \mathrm{M} \mathrm{HCl}$. Initial $\mathrm{SiO}_{2}$ concentrations were achieved through addition of Baker Analyzed sodium metasilicate nonahydrate $\left(\mathrm{Na}_{2} \mathrm{SiO}_{3} \cdot 9 \mathrm{H}_{2} \mathrm{O}\right)$ directly to the solution. Desired initial $\mathrm{Mg}$ concentrations were achieved by adding American Chemical Society (ACS) reagent-grade magnesium chloride hexahydrate $\left(\mathrm{MgCl}_{2} \cdot 6 \mathrm{H}_{2} \mathrm{O}\right)$ directly into 
solutions. In the experiment plotted in Figure A1d, sepiolite $(0.5 \mathrm{~g} / 125 \mathrm{~mL}$ of solution, consistent with [35]) was used to facilitate growth. $\mathrm{A} \mathrm{MgCl}_{2}$ brine was prepared using ACS reagent-grade $\mathrm{MgCl}_{2} \cdot 6 \mathrm{H}_{2} \mathrm{O}$ and ultrapure $(18 \mathrm{M} \Omega-\mathrm{cm})$ water, and added to the solutions via pipette until nearly all $\mathrm{SiO}_{2}$ in solution was reacted (Figure A1d). The solution was mixed on an orbital shaker and kept in a climate-controlled $\left(21.5 \pm 0.6^{\circ} \mathrm{C}\right)$ laboratory. Throughout the experiments, $3 \mathrm{~mL}$ samples were taken periodically using a syringe, filtered, and acidified while awaiting analysis for $\mathrm{Si}, \mathrm{Mg}$, and $\mathrm{Na}$ using ICP-OES [35]. The $\mathrm{pH}$ was measured on an aliquot of each sample using a Thermo Scientific PerpHecT Orion ROSS (Thermo Fisher Scientific, Waltham, MA, USA) combination $\mathrm{pH}$ microelectrode, which was calibrated at least daily using NIST-traceable $\mathrm{pH} \mathrm{4,} \mathrm{7,} \mathrm{and} 10$ buffers.

a
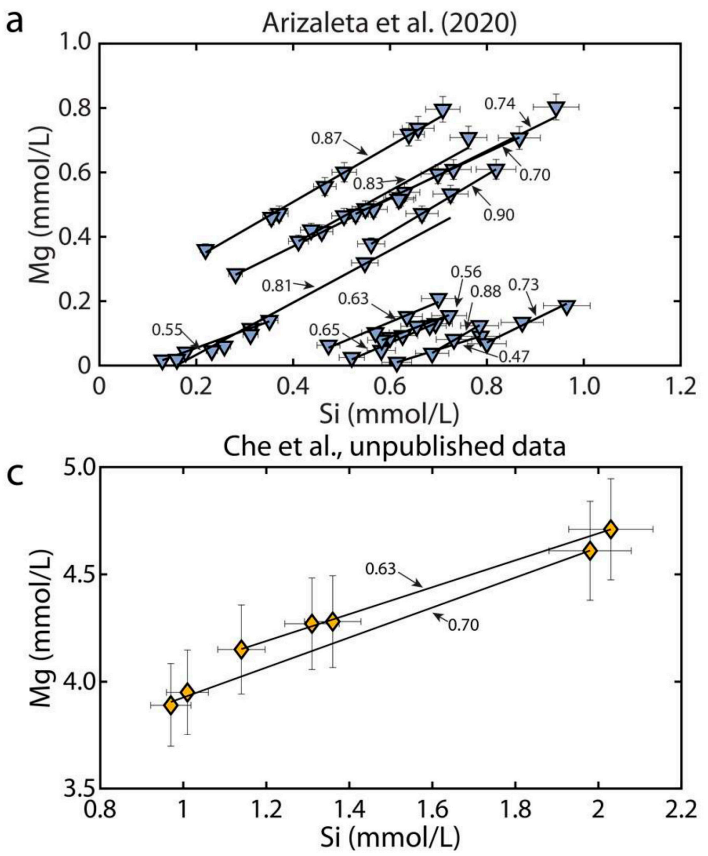
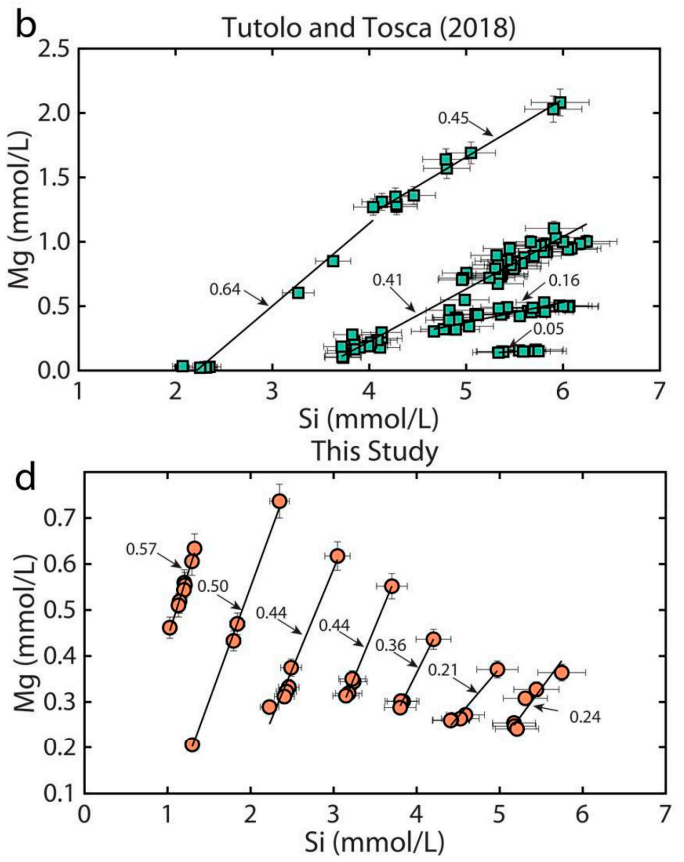

Figure A1. Mg concentrations plotted as a function of Si concentrations in the room-temperature experiments collected and analyzed in this study: (a) Arizaleta et al. [35]; (b) Tutolo and Tosca [45]; (c) Che et al. (unpublished); and (d) experiments performed during the preparation of the present study. Labels indicate slopes of lines fitted to the data.

Experiments presented by [107] were considered but not included in Figure A1 or the analysis in Figure 3 because they did not present fluid chemistry analyses, but rather the initial $\mathrm{Mg} / \mathrm{Si}$ of the solid added to their solution and the final $\mathrm{Mg} / \mathrm{Si}$ of their solid product. This likely led to the significant deviations between their data and those plotted in Figure 3 as $\eta_{f}$ or initial $\mathrm{Mg} / \mathrm{Si}$ increased above 1 , potentially due to undissolved $\mathrm{MgO}$ limited by the insolubility of $\mathrm{Mg}$ at high $\mathrm{pH}$. Nevertheless, their experiments with initial $\mathrm{Mg} / \mathrm{Si}$ of $0.4,0.6$, and 0.8 were consistent, within uncertainty, with the data plotted in Figure S2. We also considered data from [108] but excluded it from our analyses due to its anomalously high $\mathrm{Mg} / \mathrm{Si}$ ratio and temperature at which the experiments were conducted $\left(39^{\circ} \mathrm{C}\right)$. We do however note that data from reference [107] appeared to plot along a linear trend that would pass close to the data from reference [108].

Lines were fit to the data sets plotted in Figure A1 using the York regression technique [107], which permitted uncertainties in both Mg and Si concentrations to be taken into account. These were assumed to be $\pm 5 \%$ of the measured concentration, consistent with typical uncertainties on ICP-OES analyses.

\section{Appendix D. Collection, Compilation, and Formatting of the Alkaline Lake Database}

The database (Spreadsheet S1) contains water chemistry data pertaining to alkaline lakes and their surrounding areas. The collection of samples spans almost a century and 
thus contains an array of collection procedures, which can be found in the referenced papers $[8,28,29,62,67,68,75,76,92-101]$. Ten previously unpublished samples were included in the database. For these samples, sampling occurred at Last Chance and Goodenough Lakes, British Columbia, Canada, and included one spring source. Analysis of water chemistry was conducted at the University of Calgary. All data are reported in $\mathrm{mmol} / \mathrm{kg}$. To achieve this, data originally reported in $\mathrm{mg} / \mathrm{L}$ were converted assuming a solution density of $1 \mathrm{~kg}$ per $\mathrm{L}$.

The original data can be found in the "a" labeled tab of the spreadsheet, from $[8,29,67,75,76,95-100]$. Where silica concentration was reported in $\mathrm{Si}(\mathrm{mg} / \mathrm{L})$ it was converted into $\mathrm{SiO}_{2}$. When available, alkalinity data were converted into meq/L units according to:

$$
\operatorname{Alk}(\mathrm{meq} / \mathrm{L})=\frac{\operatorname{Alk}\left(\frac{\mathrm{mg}}{\mathrm{L}}\right) \times|\mathrm{Z}|}{\text { molecular weight }} .
$$

If the original units of $\mathrm{mg} / \mathrm{L}$ were not given, our calculations assumed that values were reported relative to the standard $\mathrm{mg} / \mathrm{L} \mathrm{HCO}_{3}{ }^{-}$and were converted into meq/L on that assumption. This applies to data from Mohamed et al. [98]. Charge balance error was calculated for every sample and expressed as a percentage using:

$$
C B E=\frac{\mid \sum \text { cation } \times \text { valence }|-| \sum \text { anion } \times \text { valence } \mid}{\mid \sum \text { cation } \times \text { valence }|+| \sum \text { anion } \times \text { valence } \mid} \times 100 \% .
$$

A magnitude of $C B E \leq \pm 5 \%$ is typically considered acceptable, but for the sake of inclusion and acknowledging the challenging nature of analyzing alkaline lake samples, we used all data with $C B E \leq \pm 10 \%$ in Figures 4 and 5 . All data, even those with much greater charge balance, were included in the spreadsheet for completeness. Data from associated wetlands, wells, springs, and groundwater were included in the database and are also plotted in Figure 4. Fields without available analyses are represented by 0 in the compilation. Finally, in reference [97], $\mathrm{Al}$ and $\mathrm{Fe}$ are reported as a single value and thus were not converted from ppm to mol-based units. Using the geochemical methods described in Appendix A, activities of $\mathrm{Mg}^{++}$and $\mathrm{SiO}_{2}(\mathrm{aq})$, and saturation indices for amorphous silica $\left(\mathrm{SiO}_{2}(\mathrm{am})\right.$ and the critical supersaturation for $\mathrm{Mg}$-silicate nucleation were calculated. For all calculations, temperature was assumed to be $25^{\circ} \mathrm{C}$. Some analyses did not report concentrations of $\mathrm{Mg}, \mathrm{SiO}_{2}(\mathrm{aq})$, or both. In these instances, we were unable to calculate saturation indices or the relevant species' activity.

\section{References}

1. Eugster, H.P. Geochemistry of evaporitic lacustrine deposits. Annu. Rev. Earth Planet. Sci. 1980, 8, 35-63. [CrossRef]

2. Karpeta, W.P. Bedded cherts in the Rietgat Formation, Hartbeesfontein, South Africa: A late Archaean to early Proterozoic magadiitic alkaline playa lake deposit? S. Afr. J. Geol. 1989, 92, 29-36.

3. Jones, B.E.; Grant, W.D.; Duckworth, A.W.; Owenson, G.G. Microbial diversity of soda lakes. Extremophiles 1998, 2, 191-200. [CrossRef]

4. Stüeken, E.E.; Martinez, A.; Love, G.; Olsen, P.E.; Bates, S.; Lyons, T.W. Effects of pH on redox proxies in a Jurassic rift lake: Implications for interpreting environmental records in deep time. Geochim. Cosmochim. Acta 2019, 252, 240-267. [CrossRef]

5. Stüeken, E.E.; Tino, C.; Arp, G.; Jung, D.; Lyons, T.W. Nitrogen isotope ratios trace high-pH conditions in a terrestrial Mars analog site. Sci. Adv. 2020, 6, 1-9. [CrossRef]

6. Toner, J.D.; Catling, D.C. A carbonate-rich lake solution to the phosphate problem of the origin of life. Proc. Natl. Acad. Sci. USA 2019. [CrossRef]

7. Melack, J.M.; Kilham, P. Photosynthetic rates of phytoplankton in East African alkaline, saline lakes. Limnol. Oceanogr. 1974, 19, 743-755. [CrossRef]

8. Zorz, J.K.; Sharp, C.; Kleiner, M.; Gordon, P.M.K.; Pon, R.T.; Dong, X.; Strous, M. A shared core microbiome in soda lakes separated by large distances. Nat. Commun. 2019, 10,1-10. [CrossRef]

9. Talling, J.F.; Wood, R.B.; Prosser, M.V.; Baxter, R.M. The upper limit of photosynthetic productivity by phytoplankton: Evidence from Ethiopian soda lakes. Freshw. Biol. 1973, 3, 53-76. [CrossRef]

10. Cole, J.J.; Prairie, Y.T.; Caraco, N.F.; McDowell, W.H.; Tranvik, L.J.; Striegl, R.G.; Duarte, C.M.; Kortelainen, P.; Downing, J.A.; Middelburg, J.J.; et al. Plumbing the global carbon cycle: Integrating inland waters into the terrestrial carbon budget. Ecosystems 2007, 10, 171-184. [CrossRef] 
11. Tranvik, L.J.; Downing, J.A.; Cotner, J.B.; Loiselle, S.A.; Striegl, R.G.; Ballatore, T.J.; Dillon, P.; Finlay, K.; Fortino, K.; Knoll, L.B.; et al. Lakes and reservoirs as regulators of carbon cycling and climate. Limnol. Oceanogr. 2009, 54, $2298-2314$. [CrossRef]

12. Finlay, K.; Vogt, R.J.; Bogard, M.J.; Wissel, B.; Tutolo, B.M.; Simpson, G.L.; Leavitt, P.R. Decrease in $\mathrm{CO}_{2}$ efflux from northern hardwater lakes with increasing atmospheric warming. Nature 2015, 519, 215-218. [CrossRef]

13. Canon-Rubio, K.A.; Sharp, C.E.; Bergerson, J.; Strous, M.; la Hoz Siegler, H. Use of highly alkaline conditions to improve cost-effectiveness of algal biotechnology. Appl. Microbiol. Biotechnol. 2016, 100, 1611-1622. [CrossRef] [PubMed]

14. Wright, V.P.; Barnett, A.J. An abiotic model for the development of textures in some South Atlantic early Cretaceous lacustrine carbonates. Geol. Soc. Spec. Publ. 2015, 418, 209-219. [CrossRef]

15. Tosca, N.J.; Wright, V.P. Diagenetic pathways linked to labile Mg-clays in lacustrine carbonate reservoirs: A model for the origin of secondary porosity in the Cretaceous pre-salt Barra Velha Formation, offshore Brazil. Geol. Soc. Spec. Publ. 2018, 435, 33-46. [CrossRef]

16. Pietzsch, R.; Tedeschi, L.R.; Oliveira, D.M.; dos Anjos, C.W.D.; Vazquez, J.C.; Figueiredo, M.F. Environmental conditions of deposition of the Lower Cretaceous lacustrine carbonates of the Barra Velha Formation, Santos Basin (Brazil), based on stable carbon and oxygen isotopes: A continental record of $\mathrm{pCO}_{2}$ during the onset of the Oceanic Anoxic Event. Chem. Geol. 2020, 535, 119457. [CrossRef]

17. Gomes, J.P.; Bunevich, R.B.; Tedeschi, L.R.; Tucker, M.E.; Whitaker, F.F. Facies classification and patterns of lacustrine carbonate deposition of the Barra Velha Formation, Santos Basin, Brazilian Pre-salt. Mar. Pet. Geol. 2020, 113, 104176. [CrossRef]

18. Olivito, J.P.R.; Souza, F.J. Depositional model of early Cretaceous lacustrine carbonate reservoirs of the Coqueiros formationNorthern Campos Basin, southeastern Brazil. Mar. Pet. Geol. 2020, 111, 414-439. [CrossRef]

19. Carminatti, M.; Wolff, B.; Gamboa, L. New exploratory frontiers in Brazil. In Proceedings of the 19th World Petroleum Congress, Madrid, Spain, 29 June-3 July 2008.

20. Herlinger, R.; Zambonato, E.E.; De Ros, L.F. Influence of Diagenesis On the Quality of Lower Cretaceous Pre-salt Lacustrine Carbonate Reservoirs from Northern Campos Basin, Offshore Brazil. J. Sediment. Res. 2017, 87, 1285-1313. [CrossRef]

21. Pozo, M.; Galán, E. Magnesian clay deposits: Mineralogy and origin. In Magnesian Clays: Characterization, Origin and Applications; Digilabs: Bari, Italy, 2015; pp. 175-228.

22. Jones, B.F.; Galan, E.H. Sepiolite and palygorskite. Rev. Mineral. 1988, 19, 631-674.

23. Tosca, N.J. Geochemical pathways to Mg-clay formation. Magnes. Clays Charact. Orig. Appl. 2015, 2, $283-329$.

24. Eugster, H.P.; Hardie, L.A. Saline Lakes. In Lakes; Springer: New York, NY, USA, 1978; pp. 237-293.

25. Hardie, L.A.; Eugster, H.P. Evolution of closed-basin brines. Miner. Soc. Amer. Spec. Pap. 1970, 290, $273-290$.

26. García-Ruiz, J.M. Carbonate precipitation into alkaline silica-rich environments. Geology 1998, 26, 843-846. [CrossRef]

27. Stumm, W.; Morgan, J.J. Aquatic Chemistry: Chemical Equilibria and Rates in Natural Waters; John Wiley \& Sons: New York, NY, USA, 1996.

28. Darragi, F.; Tardy, Y. Authigenic trioctahedral smectites controlling $\mathrm{pH}$, alkalinity, silica and magnesium concentrations in alkaline lakes. Chem. Geol. 1987, 63, 59-72. [CrossRef]

29. Power, I.M.; Wilson, S.A.; Harrison, A.L.; Dipple, G.M.; Mccutcheon, J.; Southam, G.; Kenward, P.A. A depositional model for hydromagnesite-magnesite playas near Atlin, British Columbia, Canada. Sedimentology 2014, 61, 1701-1733. [CrossRef]

30. Garrels, R.M.; Mackenzie, F.T. Origins of the chemical composition of some springs and lakes. In Equilibrium Concepts in Natural Water Systems; American Chemical Society: Washington, DC, USA, 1967; pp. 222-242.

31. Edmonds, M.; Tutolo, B.; Iacovino, K.; Moussallam, Y. Magmatic carbon outgassing and uptake of $\mathrm{CO}_{2}$ by alkaline waters. Am. Mineral. 2020, 105, 28-34. [CrossRef]

32. Deocampo, D.M.; Berry, P.A.; Beverly, E.J.; Ashley, G.M.; Jarrett, R.E. Whole-rock geochemistry tracks precessional control of Pleistocene lake salinity at Olduvai Gorge, Tanzania: A record of authigenic clays. Geology 2017, 45, 683-686. [CrossRef]

33. Banfield, J.F.; Jones, B.F.; Veblen, D.R. An AEM-TEM study of weathering and diagenesis, Abert Lake, Oregon: II. Diagenetic modification of the sedimentary assemblage. Geochim. Cosmochim. Acta 1991, 55, 2795-2810. [CrossRef]

34. Eberl, D.D.; Jones, B.F.; Khoury, H.N. Mixed-layer kerolite/stevensite from the Amargosa Desert, Nevada. Clays Clay Miner. 1982, 30, 321-326. [CrossRef]

35. Arizaleta, M.L.; Nightingale, M.; Tutolo, B.M. A rate law for sepiolite growth at ambient temperatures and its implications for early lacustrine diagenesis. Geochim. Cosmochim. Acta 2020, 288, 301-315. [CrossRef]

36. Mulders, J.J.P.A.; Oelkers, E.H. An experimental study of sepiolite dissolution rates and mechanisms at $25^{\circ} \mathrm{C}$. Geochim. Cosmochim. Acta 2020, 270, 296-312. [CrossRef]

37. Galán, E.; Pozo, M. Palygorskite and sepiolite deposits in continental environments. Description, genetic patterns and sedimentary settings. In Developments in Clay Science; Elsevier Science: Amsterdam, The Netherlands, 2011; Volume 3, pp. 125-173, ISBN 9780444536075 .

38. Deocampo, D.M. Authigenic clay minerals in lacustrine mudstones. Spec. Pap. Geol. Soc. Am. 2015, 515, 49-64. [CrossRef]

39. Pozo, M.; Casas, J. Origin of kerolite and associated Mg clays in palustrine-lacustrine environments. The Esquivias deposit (Neogene Madrid Basin, Spain). Clay Miner. 1999, 34, 395-418. [CrossRef]

40. Fahey, J.J.; Ross, M.; Axelrod, J.M. Loughlinite: A new hydrous sodium magnesium silicate. Am. Mineral. 1960, 45, $270-281$.

41. Jones, B.F. Clay mineral diagenesis in lacustrine sediments. US Geol. Surv. Bull. 1986, 1578, 291-300. 
42. Wollast, R.; Mackenzie, F.T.; Bricker, O.P. Experimental Precipitation and Genesis of Sepiolite at Earth-Surface Conditions. Am. Mineral. 1968, 53, 1645-1662.

43. Tosca, N.J.; Macdonald, F.A.; Strauss, J.V.; Johnston, D.T.; Knoll, A.H. Sedimentary talc in Neoproterozoic carbonate successions. Earth Planet. Sci. Lett. 2011, 306, 11-22. [CrossRef]

44. Tosca, N.J.; Masterson, A.L. Chemical controls on incipient Mg-silicate crystallization at $25^{\circ} \mathrm{C}$ : Implications for early and late diagenesis. Clay Miner. 2014, 49, 165-194. [CrossRef]

45. Tutolo, B.M.; Tosca, N.J. Experimental examination of the Mg-silicate-carbonate system at ambient temperature: Implications for alkaline chemical sedimentation and lacustrine carbonate formation. Geochim. Cosmochim. Acta 2018, 225, 80-101. [CrossRef]

46. Mercedes-Martín, R.; Rogerson, M.R.; Brasier, A.T.; Vonhof, H.B.; Prior, T.J.; Fellows, S.M.; Reijmer, J.J.G.; Billing, I.; Pedley, H.M. Growing spherulitic calcite grains in saline, hyperalkaline lakes: Experimental evaluation of the effects of Mg-clays and organic acids. Sediment. Geol. 2016, 335, 93-102. [CrossRef]

47. Wright, V.P.; Barnett, A. Cyclicity and Carbonate-Silicate Gel Interactions in Cretaceous Alkaline Lakes. AAPG Annu. Conv. Ehibition 2014, 51011, 18.

48. Baldermann, A.; Mavromatis, V.; Frick, P.M.; Dietzel, M. Effect of aqueous Si/Mg ratio and pH on the nucleation and growth of sepiolite at $25^{\circ} \mathrm{C}$. Geochim. Cosmochim. Acta 2018, 227, 211-226. [CrossRef]

49. Tosca, N.J.; Knoll, A.H. Juvenile chemical sediments and the long term persistence of water at the surface of Mars. Earth Planet. Sci. Lett. 2009, 286, 379-386. [CrossRef]

50. Bish, D.L. X-ray Diffraction Results from Mars. Science 2014, 1-6. [CrossRef]

51. Kloprogge, J.T.; Komarneni, S.; Amonette, J.E. Synthesis of smectite clay minerals: A critical review. Clays Clay Miner. 1999, 47, 529-554. [CrossRef]

52. Granquist, W.T.; Pollack, S.S. A study of the synthesis of hectorite. Clays Clay Miner. 1959, 8, 150-169. [CrossRef]

53. Harder, H. The role of magnesium in the formation of smectite minerals. Chem. Geol. 1972, 10, 31-39. [CrossRef]

54. Vogels, R.J.M.J.; Kerkhoffs, M.J.H.V.; Geus, J.W. Non-hydrothermal synthesis, characterisation and catalytic properties of saponite clays. In Studies in Surface Science and Catalysis; Elsevier BV: Amsterdam, Netherlands, 1995; Volume 91, pp. $1153-1161$.

55. Decarreau, A. Partitioning of divalent transition elements between octahedral sheets of trioctahedral smectites and water. Geochim. Cosmochim. Acta 1985, 49, 1537-1544. [CrossRef]

56. Decarreau, A. Cristallogenèse expérimentale des smectites magnésiennes: Hectorite, stévensite. Bull. Minéralogie 1980, 103, 579-590. [CrossRef]

57. Berner, R.A. Early Diagenesis: A Theoretical Approach; Princeton University Press: Princeton, NJ, USA, 1980.

58. Wright, V.P. Lacustrine carbonates in rift settings: The interaction of volcanic and microbial processes on carbonate deposition. Geol. Soc. Spec. Publ. 2012, 370, 39-47. [CrossRef]

59. Saller, A.; Rushton, S.; Buambua, L.; Inman, K.; McNeil, R.; Dickson, J.A.D.T. Presalt stratigraphy and depositional systems in the Kwanza Basin, offshore Angola. Am. Assoc. Pet. Geol. Bull. 2016, 100, 1135-1164. [CrossRef]

60. Wright, V.P.; Barnett, A.J. The textural evolution and ghost matrices of the Cretaceous Barra Velha Formation carbonates from the Santos Basin, offshore Brazil. Facies 2020, 66, 1-18. [CrossRef]

61. Deocampo, D.M.; Ashley, G.M. Siliceous islands in a carbonate sea: Modern and Pleistocene spring-fed wetlands in Ngorongoro crater and Oldupai Gorge, Tanzania. J. Sediment. Res. 1999, 69, 974-979. [CrossRef]

62. Deocampo, D.M. Evaporative evolution of surface waters and the role of aqueous $\mathrm{CO}_{2}$ in magnesium silicate precipitation: Lake Eyasi and Ngorongoro crater, northern Tanzania. S. Afr. J. Geol. 2005, 108, 493-504. [CrossRef]

63. Stoessell, R.K. $25^{\circ} \mathrm{C}$ and $1 \mathrm{~atm}$ dissolution experiments of sepiolite and kerolite. Geochim. Cosmochim. Acta 1988, 52, 365-374. [CrossRef]

64. Birsoy, R. Formation of sepiolite-palygorskite and related minerals from solution. Clays Clay Miner. 2002, 50, 736-745. [CrossRef]

65. Hay, R.L.; Hughes, R.E.; Kyser, T.K.; Glass, H.D.; Liu, J. Magnesium-rich clays of the meerschaum mines in the Amboseli basin, Tanzania and Kenya. Clays Clay Miner. 1995, 43, 455-466. [CrossRef]

66. Khoury, H.N.; Eberl, D.D.; Jones, B.F. Origin of magnesium clays from the Amargosa Desert, Nevada. Clays Clay Miner. 1982, 30, 327-336. [CrossRef]

67. Badaut, D.; Risacher, F. Authigenic smectite on diatom frustules in Bolivian saline lakes. Geochim. Cosmochim. Acta 1983, 47, 363-375. [CrossRef]

68. Servant-Vildary, S.; Roux, M. Multivariate analysis of diatoms and water chemistry in Bolivian saline lakes. Hydrobiologia 1990, 197, 267-290. [CrossRef]

69. Ryves, D.; Juggins, S.; Fritz, S.; Battarbee, R. Experimental diatom dissolution and the quantification of microfossil preservation in sediments. Palaeogeogr. Palaeoclimatol. Palaeoecol. 2001, 172, 99-113. [CrossRef]

70. Katz, M.E.; Finkel, Z.V.; Grzebyk, D.; Knoll, A.H.; Paul, G.; Falkowski, P.G. Evolutionary trajectories and biogeochemical impacts of marine eukaryotic phytoplankton. Annu. Rev. Ecol. Evol. Syst. 2004, 35, 523-556. [CrossRef]

71. Maliva, R.G.; Knoll, A.H.; Siever, R. Secular change in chert distribution: A reflection of evolving biological participation in the silica cycle. Palaios 1989, 4, 519-532. [CrossRef]

72. Alverson, A.J.; Jansen, R.K.; Theriot, E.C. Bridging the Rubicon: Phylogenetic analysis reveals repeated colonizations of marine and fresh waters by thalassiosiroid diatoms. Mol. Phylogenet. Evol. 2007, 45, 193-210. [CrossRef] 
73. Conley, D.J.; Frings, P.J.; Fontorbe, G.; Clymans, W.; Stadmark, J.; Hendry, K.R.; Marron, A.O.; De La Rocha, C.L. Biosilicification drives a decline of dissolved si in the oceans through geologic time. Front. Mar. Sci. 2017, 4. [CrossRef]

74. Stenger-Kovács, C.; Lengyel, E.; Buczkó, K.; Tóth, F.M.; Crossetti, L.O.; Pellinger, A.; Doma, Z.Z.; Padisák, J. Vanishing world: Alkaline, saline lakes in Central Europe and their diatom assemblages. Inl. Waters 2014, 4, 383-396. [CrossRef]

75. Power, I.M.; Wilson, S.A.; Thom, J.M.; Dipple, G.M.; Gabites, J.E.; Southam, G. The hydromagnesite playas of Atlin, British Columbia, Canada: A biogeochemical model for $\mathrm{CO}_{2}$ sequestration. Chem. Geol. 2009, 260, 286-300. [CrossRef]

76. Fritz, S.C.; Juggins, S.; Battarbee, R.W. Diatom assemblages and ionic characterization of lakes of the Northern Great Plains, North America: A tool for reconstructing past salinity and climate fluctuations. Can. J. Fish. Aquat. Sci. 1993, 50, 1844-1856. [CrossRef]

77. Renberg, I.; Hellberg, T. The pH history of lakes in southwestern Sweden, as calculated from the subfossil diatom flora of the sediments. Ambio 1982, 11, 30-33. [CrossRef]

78. Dixit, S.S.; Dickman, M.D. Correlation of surface sediment diatoms with the present lake water pH in 28 Algoma lakes, Ontario, Canada. Hydrobiologia 1986, 131, 133-143. [CrossRef]

79. Sverjensky, D.A.; Shock, E.L.; Helgeson, H.C. Prediction of the thermodynamic properties of aqueous metal complexes to $1000{ }^{\circ} \mathrm{C}$ and $5 \mathrm{~kb}$. Geochim. Cosmochim. Acta 1997, 61, 1359-1412. [CrossRef]

80. Chen, C.Y.; Durbin, E.G. Effects of pH on the growth and carbon uptake of marine phytoplankton. Mar. Ecol. Prog. Ser. 1994, 109, 83-94. [CrossRef]

81. Elzenga, J.T.M.; Prins, H.B.A.; Stefels, J. The role of extracellular carbonic anhydrase activity in inorganic carbon utilization of Phaeocystis globosa (Prymnesiophyceae): A comparison with other marine algae using the isotopic disequilibrium technique. Limnol. Oceanogr. 2000, 45, 372-380. [CrossRef]

82. Humphrey, G.F. The Photosynthesis: Respiration ratio of some unicellular marine algae. J. Exp. Mar. Bio. Ecol. 1975, 18, 111-119. [CrossRef]

83. Hansen, P.J. Effect of high $\mathrm{pH}$ on the growth and survival of marine phytoplankton: Implications for species succession. Aquat. Microb. Ecoogy 2002, 28, 279-288. [CrossRef]

84. Gell, P.A. The development of a diatom database for inferring lake salinity, Western Victoria, Australia: Towards a quantitative approach for reconstructing past climates. Aust. J. Bot. 1997, 45, 389-423. [CrossRef]

85. Krebs, W.N.; Bradbury, J.P.; Theriot, E. Neogene and quaternary lacustrine diatom biochronology, western USA. Palaios 1987, 2, 505-513. [CrossRef]

86. Sims, P.A.; Mann, D.G.; Medlin, L.K. Evolution of the diatoms: Insights from fossil, biological and molecular data. Phycologia 2006, 45, 361-402. [CrossRef]

87. Trembath-Reichert, E.; Wilson, J.P.; McGlynn, S.E.; Fischer, W.W. Four hundred million years of silica biomineralization in land plants. Proc. Natl. Acad. Sci. USA 2015, 112, 5449-5454. [CrossRef]

88. Downs, R.T. The RRUFF Project: An integrated study of the chemistry, crystallography, Raman and infrared spectroscopy of minerals. In Proceedings of the 19th General Meeting of the International Mineralogical Association, Kobe, Japan, 23-28 July 2006.

89. Uher, P.; Janák, M.; Ozdín, D. Calcian dravite from metacarbonate rocks of the Mútnik magnesite-talc deposit, Hnúšt'a, Slovakia. Neues Jahrb. Fur. Mineral. Mon. 2002, 68-84. [CrossRef]

90. Bradley, W.H.; Fahey, J.J. Occurrence of Stevensite in the Green River Formation of Wyoming. Am. Mineral. 1962, 47, 996-998.

91. Bradley, W.H.; Eugster, H.P. Geochemistry and Paleolimnology of the Trona Deposits and Associated Authigenic Minerals of the Green River Formation of Wyoming; Professional Paper 496-B; U.S. Government Publishing Office: Washington, DC, USA, 1969; pp. 1-71.

92. Risacher, F.; Fritz, B. Geochemistry of Bolivian salars, Lipez, southern Altiplano: Origin of solutes and brine evolution. Geochim. Cosmochim. Acta 1991, 55, 687-705. [CrossRef]

93. Reimer, A.; Landmann, G.; Kempe, S. Lake Van, Eastern Anatolia, hydrochemistry and history. Aquat. Geochem. 2009, 15, 195-222. [CrossRef]

94. Fussmann, D.; Jean Elisabeth Von Hoyningen-Huene, A.; Reimer, A.; Schneider, D.; Babková, H.; Peticzka, R.; Maier, A.; Arp, G.; Daniel, R.; Meister, P. Authigenic formation of Ca-Mg carbonates in the shallow alkaline Lake Neusiedl, Austria. Biogeosciences 2020, 17, 2085-2106. [CrossRef]

95. Renaut, R.W. Morphology, distribution, and preservation potential of microbial mats in the hydromagnesite-magnesite playas of the Cariboo Plateau, British Columbia, Canada. Hydrobiologia 1993, 267, 75-98. [CrossRef]

96. Phillips, K.N.; Van Denburgh, A.S. Hydrology and Geochemistry of Abert, Summer, and Goose Lakes, and Other Closed-Basin Lakes in South-Central Oregon; Professional Paper 502-B; U.S. Government Publishing Office: Washington, DC, USA, 1971.

97. Rawson, D.S.; Moore, J.E. The Saline Lakes of Saskatchewan. Can. J. Res. 1944, 22, 141-201. [CrossRef]

98. Mohamed, E.A.; El-Kammar, A.M.; Yehia, M.M.; Abu Salem, H.S. Hydrogeochemical evolution of inland lakes' water: A study of major element geochemistry in the Wadi El Raiyan depression, Egypt. J. Adv. Res. 2014, 6, 1031-1044. [CrossRef]

99. Yuretich, R.F.; Cerling, T.E. Hydrogeochemistry of Lake Turkana, Kenya: Mass balance and mineral reactions in an alkaline lake. Geochim. Cosmochim. Acta 1983, 47, 1099-1109. [CrossRef]

100. Hirst, J.F. Sedimentology, Diagenesis and Hydrochemistry of the Saline, Alkaline Lakes on the Cariboo Plateau, Interior British Columbia, Canada; University of Saskatchewan: Saskatoon, SK, Canada, 1995.

101. Whitehead, H.C.; Feth, J.H. Recent Chemical Analyses of Waters from Several Closed-Basin Lakes and their Tributaries in the Western United States. Geol. Soc. Am. Bull. 1961, 72, 1421-1426. [CrossRef] 
102. Moussa, A.; Novello, A.; Lebatard, A.E.; Decarreau, A.; Fontaine, C.; Barboni, D.; Sylvestre, F.; Bourlès, D.L.; Paillès, C.; Buchet, G.; et al. Lake Chad sedimentation and environments during the late Miocene and Pliocene: New evidence from mineralogy and chemistry of the Bol core sediments. J. Afr. Earth Sci. 2016, 118, 192-204. [CrossRef]

103. Kent, D.B.; Kastner, M. $\mathrm{Mg}^{2+}$ removal in the system $\mathrm{Mg}^{2+}$-amorphous $\mathrm{SiO}_{2}-\mathrm{H}_{2} \mathrm{O}$ by adsorption and $\mathrm{Mg}$-hydroxysilicate precipitation. Geochim. Cosmochim. Acta 1985, 49, 1123-1136. [CrossRef]

104. Case, D.H.; Wang, F.; Giammar, D.E. Precipitation of magnesium carbonates as a function of temperature, solution composition, and presence of a silicate mineral substrate. Environ. Eng. Sci. 2011, 28, 881-889. [CrossRef]

105. Berninger, U.-N.; Jordan, G.; Schott, J.; Oelkers, E.H. The experimental determination of hydromagnesite precipitation rates at 22.5-75 ${ }^{\circ}$ C. Mineral. Mag. 2014, 78, 1405-1416. [CrossRef]

106. Peterson, M.N.A.; Von Der Borch, C.C. Chert: Modern Inorganic Deposition in a Carbonate-Precipitating Locality. Science 1965, 149, 1501-1503. [CrossRef]

107. Nied, D.; Enemark-Rasmussen, K.; L'Hopital, E.; Skibsted, J.; Lothenbach, B. Properties of magnesium silicate hydrates (M-S-H). Cem. Concr. Res. 2016, 79, 323-332. [CrossRef]

108. Gunnarsson, I.; Arnórsson, S.; Jakobsson, S. Precipitation of poorly crystalline antigorite under hydrothermal conditions. Geochim. Cosmochim. Acta 2005, 69, 2813-2828. [CrossRef] 